\title{
ASSESSING SUSTAINABILITY ACTIVITIES IN SPORT-RELATED SOFTWARE \\ START-UPS - AN APPLICATION OF THE TRIPLE-LAYERED \\ BUSINESS MODEL CANVAS
}

by

Hannah Behounek

Bachelor of Science, Rensselaer Polytechnic Institute, 2017

\begin{abstract}
A Professional Project Paper presented to Ryerson University in partial fulfillment of the requirements for the degree of

Master of Applied Science in the program of

Environmental Applied Science and Management
\end{abstract}

Toronto, Ontario, Canada, 2020

(C) Hannah Behounek 2020 


\section{AUTHOR'S DECLARATION FOR ELECTRONIC SUBMISSION OF AN MRP}

I hereby declare that I am the sole author of this project paper. This is a true copy of the project paper including any required final revisions.

I authorize Ryerson University to lend this project paper to other institutions or individuals for the purpose of scholarly research I further authorize Ryerson University to reproduce this project paper by photocopying or by any other means, in total or in part, at the request of other institutions or individuals for the purpose of scholarly research.

I understand that my project paper may be made electronically available to the public. 


\title{
ASSESSING SUSTAINABILITY ACTIVITIES IN SPORT-RELATED SOFTWARE START- UPS - AN APPLICATION OF THE TRIPLE-LAYERED BUSINESS MODEL CANVAS
}

\author{
Master of Applied Science, 2020 \\ Hannah Behounek \\ Environmental Applied Science and Management \\ Ryerson University
}

\begin{abstract}
Due to the increasing number of environmental and social issues present in society, sustainability is viewed as the mechanism to remedy these issues. Researchers believe sustainability at the societal level is impossible without businesses embracing it first, and that the business model is the key component to integrate sustainability throughout the entire business. Start-ups are considered the ideal foundation for achieving sustainability in businesses, as this is when the business model is usually developed and refined. However, few start-ups are founded with sustainability activities incorporated into the business model. This project examines three software-based start-ups to understand what current or potential future environmental and social considerations are or could be incorporated into the business models, how the entrepreneurs view sustainability activities in relation to their start-ups, and how they view sustainability activities effect on receiving funding from venture capitalists. It is found that the three start-ups have very limited current and potential environmental and social considerations in their business model. Only one entrepreneur believes that sustainability and having environmental and social considerations can help receive funding from venture capitals.
\end{abstract}




\section{ACKNOWLEDGEMENTS}

I would like to recognize the invaluable assistance of my two supervisors, Dr. Michal Bardecki and Dr. Phil Walsh, who have been immensely helpful and provided expert guidance throughout this entire endeavour. Dr. Michal Bardecki provided a great deal of sustainability knowledge and support throughout this entire process. Dr. Phil Walsh provided invaluable connections and expertise in the areas of entrepreneurship and innovation. I would like to express my gratitude to both of them, who have stuck with me when this project faced setbacks and provided guidance and reassurance throughout all the different directions this project took. I would also like to thank the Environmental Applied Science and Management program for allowing me to pursue this research while earning a master's degree. 


\section{TABLE OF CONTENTS}

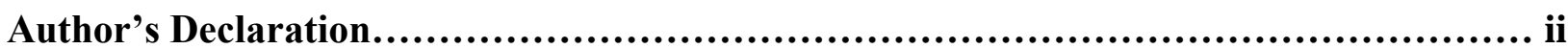

Abstract.......................................................................................... ii

Acknowledgements............................................................................... iv

List of Tables................................................................................. vi

List of Figures.............................................................................. vii

List of Appendices........................................................................ vii

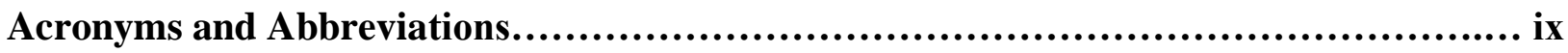

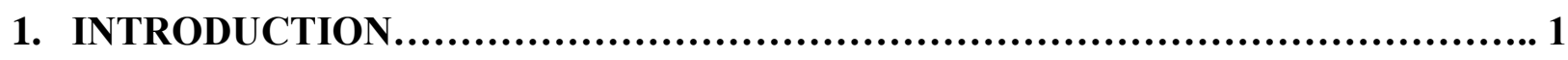

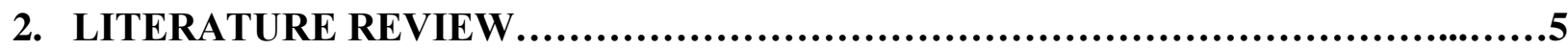

2.1 Blended Value and Sustainability in Start-ups...................................

2.2 Sustainability and Venture Capitalism........................................ 14

2.3 Sustainability in Sports....................................................... 15

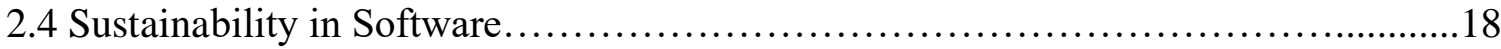

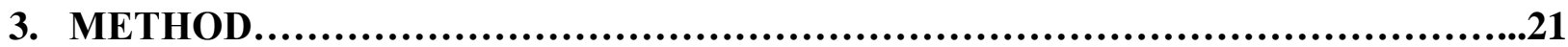

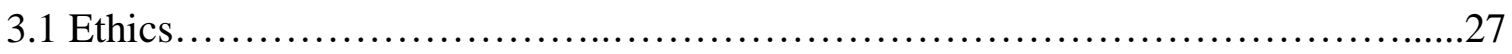

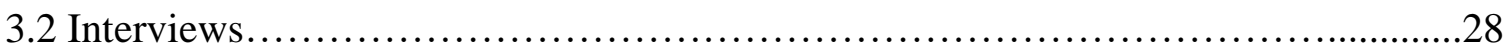

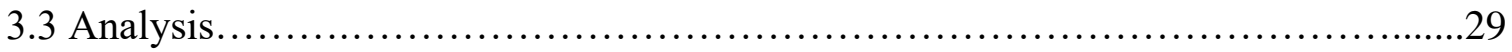

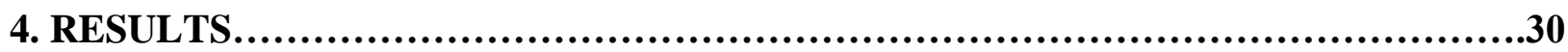

4.1 Performance Phenomics........................................................ 30

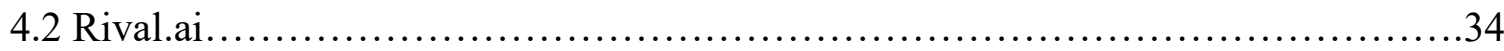

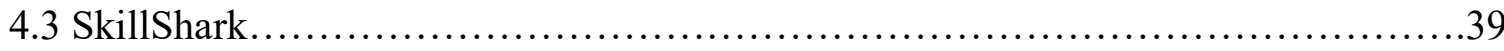

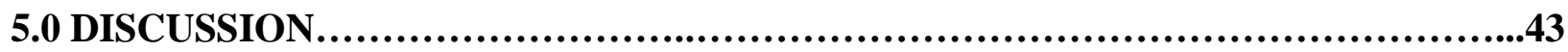

5.1 Performance Phenomics.....................................................................

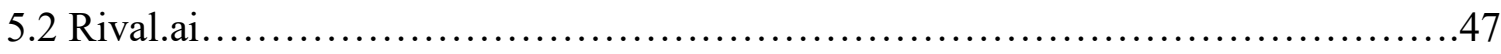

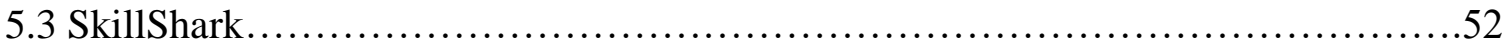

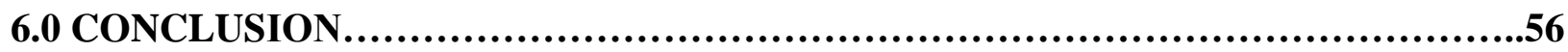

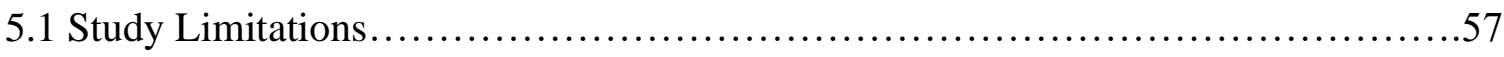

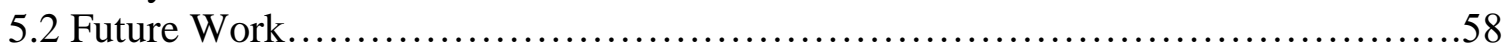

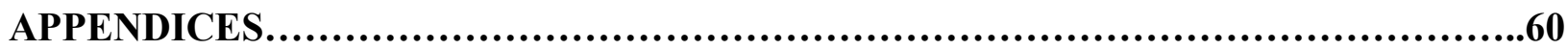

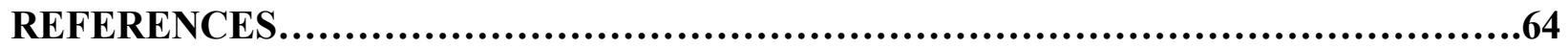




\section{LIST OF TABLES}

Table 1 - Seven competencies required by a business to achieve sustainable development......13

Table 2 - Five general rules that guide sustainability-driven entrepreneurs....................14 


\section{LIST OF FIGURES}

Figure 1 - Osterwaler and Pigneur's (2010) Business Model Canvas........................22

Figure 2 - The horizontal coherence and vetical coherence of the TLBMC (Joyce \& Paquin, 2016).

Figure 3 - The Environmental Life Cycle Business Model Canvas (Joyce \& Paquin, 2016)....24

Figure 4 - The Social Stakeholder Business Model (Joyce \& Paquin, 2016)................26

Figure 5 - Performance Phenomics' Environmental Layer................................32

Figure 6 - Performance Phenomics' Social Layer ..........................................

Figure 7 - Rival.ai's Environmental Layer............................................... 37

Figure 8 - Rival.ai's Social Layer............................................ 38

Figure 9 - SkillShark's Environmental Layer.......................................41

Figure 10 - SkillShark's Social Layer .........................................42 


\section{LIST OF APPENDICES}

Appendix A - Interview Questions.............................................6

Appendix B - Follow-up Questions............................................63 


\section{ABBREVIATIONS}

BMC Business Model Canvas

BV Blended value

CSR Corporate social responsibility

FDA Food and Drug Administration

FSL Future of Sport Lab

FSSD Framework for Strategic Sustainable Design

ICT Information and communications technology

MLSE Maple Leafs Sports Entertainment

MRI Magnetic Resonance Imaging

PP Performance Phenomics

R.ai Rival.ai

SS SkillShark

SBM Sustainable Business Model

SSBMC Strongly Sustainable Business Model Canvas

TLBMC Triple Layered Business Model Canvas

VCs Venture capitalists 


\subsection{INTRODUCTION}

Critics often attribute many of the negative externalities of business to the sole focus of achieving financial success (McMullen \& Warnick, 2016). These negative externalities have led to environmental problems such as pollution, biodiversity decline, and climate change, as well as social problems such as employee health and safety issues, and poor community relationships (Vogel, 1992). These issues have led to many international organizations, governments, and researchers expressing the need for sustainable development (Schaltegger et al., 2016). Defined over thirty years ago by the World Commission on Environment and Development in Our Common Future, sustainable development is development that "meets the needs of the present without compromising the ability of future generations to meet their own needs" (WCED, 1987, p. 29). Sustainable development can be considered an element in achieving sustainability, which has become a widely used term throughout many different disciplines and contexts (Brown et al., 1987; Basiago, 1995; Sikdar, 2003).

While there are many different variations and uses of the term sustainability, such as in biology, economics, ethics, sociology, and urban planning domains (Basiago, 1995), the general notion of the term refers to something being able to be upheld, or maintained indefinitely. Currently, sustainability is most commonly recognized as "the three pillars," represented by intersecting economic, environmental, and social circles, where overall sustainability is at the centre (Purvis et al., 2019). Diesendorf (2002) explains that sustainable development is characterized by the concept of sustainability - overall sustainability is the goal and sustainable development is the process of achieving sustainability.

The main concern regarding applying sustainability is through the use of capital, whether economic, environmental, or social. A major dilemma in sustainability research is whether 
different kinds of capital can be substituted by one another in order to achieve sustainability. This dilemma is explained by the concepts of weak sustainability and strong sustainability (Pearce et al., 1989; Neumayer, 1999; Figge \& Hahn, 2004). Weak sustainability proposes that all forms of capital are substitutable - meaning that sustainability in a system can still be achieved if a loss in one form is replaced by a surplus in another form (Figge \& Hahn, 2004). On the other hand, strong sustainability assumes that each form of capital is complementary, but not interchangeable, such that humans cannot alter environmental capital to create economic capital. More specifically, strong sustainability can be explained through the model where the economy is embedded within society, which is embedded within the environment, thus economic and social activities are constrained by environmental factors (Figge \& Hahn, 2004).

Many scholars believe that achieving sustainable development at the societal level is impossible without organizations, especially businesses, embracing sustainable development first (Hall et al., 2010; Parrish, 2010; Schaltegger et al., 2016). Businesses are aware of this and have begun adopting sustainability aspects; however, the typical approaches by businesses in achieving sustainable development, approaches such as philanthropy and corporate social responsibility, have not been sufficient in achieving substantial sustainable development (Schaltegger et al., 2016; França et al., 2017).

In order to more effectively contribute to sustainable development, researchers have identified the business model as a key component to better integrate sustainability throughout businesses (Stubbs \& Cocklin, 2008; Boons \& Lüdeke-Freund, 2013; Schaltegger et al., 2016). Additionally, start-ups, which can be generally characterized as young-companies, are believed to be an ideal foundation for achieving sustainable development as this is the stage during which the business model is developed and many long-term decisions are made (Herstatt \& Verworn, 2004; 
Bocken et al., 2014; Bocken, 2015). Choices made by entrepreneurs in the early phases of businesses play a critical role in their future impacts on the environment and society (Herstatt \& Verworn, 2004; Bocken et al., 2014; Bocken, 2015). These choices may create positive and/or reduce negative environmental and/or social impacts (Bocken et al., 2014). Research in this area is increasing. A search of the terms "sustainable development" and "start-ups" using Google Scholar from 2000 to 2020 found 17,800 publications while from 2015 to 2020 that number was 8,430 . As nearly half of publications with these terms have been published in the last 5 years, this suggests that research in this field continues to be emerging.

A Blended Value (BV) approach has been suggested as one way in which corporations can more thoroughly incorporate sustainability aspects and better contribute to sustainable development. This approach originates from the BV theory, which states that the negative externalities of businesses, which are often social and environmental externalities, can be avoided by incorporating social and environmental dimensions of value into the business model (Emerson, 2003). Incorporating BV into a business model can help create start-ups that are commercially viable, but also sustainable, in the sense of creating value that is concurrently economic, environmental, and social (Emerson, 2003; Lindgreen et al., 2018).

While it is well accepted that businesses need to adopt these values, very few start-ups include BV in their business model (Parrish, 2010; França et al., 2017). Given that businesses may be key to achieving sustainable development, it raises the question "why are start-ups not incorporating BV?". This project hopes to answer this question by aiming to understand some of the motivators, if any, for entrepreneurs when faced with the option to incorporate BV into their business model. As the entrepreneurs selected all have founded sport-related software start-ups, 
the project will be focussed on understanding how sustainability is implemented in the software and sports industries.

The project is carried through conducting informal interviews with three sport-related software start-ups who have recently designed their business model. The three start-ups selected are recent "graduates" of the Future of Sport Lab (FSL), an innovation incubator jointly-sponsored by both Maple Leafs Sports Entertainment Ltd. (MLSE) and Ryerson University in Toronto, Ontario. Informal interviews and follow-up questions with the entrepreneurs of each start-up aimed to gather deeper insight into their product or service, their business model, and their opinions on incorporating environmental and social considerations into their business model.

The objectives of this project are to:

- Understand what environmental and social considerations have already been implemented into the start-up's business models.

- Gain insight into entrepreneur's opinions on what environmental and social considerations may be important to implement into their business model and their general views on sustainability.

- Understand entrepreneur's views on the role sustainability activities have on receiving funding from venture capitalists (VCs). 


\subsection{LITERATURE REVIEW}

The current research regarding BV and sustainability in start-ups, BV's role in venture capitalism, sustainability in the sports industry, and sustainability in software and information and communication technology is discussed in the following sections. The first section discusses the importance of innovation and sustainable business models (SBMs), as well as examples of popular frameworks used to design SBMs, followed by the role start-ups play in developing SBMs. The first section concludes with explaining the link between SBMs and BV theory. The second section explains the role incorporating sustainability, through a BV business model, may play in securing funding and thus survival for start-ups. The third section focuses on the current sustainability practices in the sports industry. The final section reviews the current state of sustainability and software, as all three start-ups are software-based companies within the sports industry.

\subsection{Blended Value and Sustainability in Start-ups}

Researchers have begun voicing the critical need for society to transition to sustainable development (Hall et al., 2010; Parrish, 2010; Bocken et al., 2015; Boons et al., 2015; Schaltegger et al., 2016; Baldassarre et al., 2017; França et al., 2017). A consensus among sustainability researchers has emerged expressing that sustainable development at the societal level is likely not possible without businesses adopting sustainable development (Schaltegger et al., 2016). Additionally, current sustainability approaches by businesses have been insufficient in achieving sustainable development (Schaltegger et al., 2016). Implementing corporate social responsibility programs, publishing sustainability reports, and hiring sustainability managers are some examples of the current approaches for including sustainability into businesses. While these have resulted in some positive results, many researchers note that these approaches struggle to embed sustainability 
throughout the entire or businesses' value creation process, making further advances to sustainable development difficult (Bocken et al., 2014; Bocken, 2015; França et al., 2017).

The Centre for Sustainable Design (2007) defines sustainable innovation as a "process where sustainability considerations are integrated into company systems from idea generation through to research development and commercialization" (p. 9). Many scholars suggest that true sustainable development requires sustainable innovation, which has subsequently seen increased research interest in the last five years (Aghion et al., 2009; Europe INNOVA, 2011; Boons et al., 2013). Boons et al. (2013) attribute this spike in sustainable innovation research to the large number of "un-sustainability" issues, such as climate change, population increase, desertification, water scarcity, pollution, and critical raw materials scarcities that are so prevalent throughout the world (p. 2).

Sustainable Business Models (SBMs)

More specifically, the innovation and design of SBMs is thought to be one of the key factors in achieving sustainable development (Boons \& Wagner, 2009; Boons et al., 2013; Schaltegger et al., 2016; França et al., 2017). Kiron et al. (2013) state that completely incorporating sustainability into an organization is not only possible for businesses, but will be required in order to be competitive in the future. Business model innovation could be the critical lever to achieve this. According to Bocken (2015), a fundamental change of business and business models is necessary in order to achieve sustainability of a business. Boons and Wagner (2009) propose that SBMs are the link between sustainable innovation and better economic performance. Thus, sustainable innovation linked to new business models is a win-win solution in dealing with "unsustainability" issues as well as the possible future economic health of a business (Porter \& Kramer, 2011). 
While it is generally agreed upon by researchers that innovation and business model design is key to sustainable development, França et al. (2017) note that it has been a historically neglected approach when attempting to deal with sustainability challenges. Current business models have generally failed in successfully embracing sustainability due to a variety of reasons: poor planning in integrating sustainability, too narrow of a scope, and limited knowledge of sustainability (França et al., 2017). However, as with sustainable innovation, research in the area of SBMs is drawing increased interest within the literature (Boons et al., 2013; Bocken et al., 2014; Schaltegger et al., 2016; Upward \& Jones, 2016; Kurucz et al., 2017; Clinton \& Whisnant, 2019).

The increased research interest in SBMs has led to a variety of definitions of what exactly constitutes a SBM. According to Garetti and Taisch (2012), SBMs preserve the environment while also improving the quality of human life. Lüdeke-Freund (2010, p. 23) explains that SBMs create "competitive advantage through superior customer value and contribute to a sustainable development of the company and society”. Bocken et al. (2014) and Stubbs and Cocklin (2008) have similar, but more robust definition of SBMs. In Bocken et al.'s definition, SBMs extend from the triple bottom line approach in all operations, meaning the business monitors environmental and social performance of their business just as they do economical. SBMs also identify a wider range of stakeholders and their interests, including the environment and society (Bocken et al., 2014). Stubbs and Cocklin (2008) perform a broad literature review on SBMs and develop a number of comprehensive features of them. As explained by Stubbs and Cocklin (2008), a SBM is one that draws on economic, environmental, and social aspects in defining a businesses' purpose, uses a triple bottom line approach, considers the needs of all stakeholders - one being nature, have sustainability leaders drive the culture of the business, and have a system and firm-level perspective. 


\section{Blended Value Theory}

Another area scholars have identified as important is the process of how businesses actually develop a SBM. One area of SBM development research is witnessed in BV theory, developed by Emerson (2003). BV theory claims that value is not only found in economic or social terms, but rather through a merging of economic, social, and environmental dimensions. Investments then contribute simultaneously to economic, social, and environmental objectives. Emerson (2003, p. 38) also states that there is no "trade off" between the three, and thus all returns from investing create value that is a blend of economic, social, and environmental capital.

Elkington et al. (2006) expand on BV theory, specifically how BV theory can be applied to businesses and organizations in order to achieve $\mathrm{BV}$ in practice. They explain that businesses aim to create value, which can come in many different varieties. To achieve BV, Elkington et al. (2006, p.6) explain that businesses need to create "Value Blends," which are combinations of the multiple different dimensions of value created by a business that successfully cater to the different needs and preferences of consumers, customers, and investors. Laasch (2018) also highlights the importance of BV for businesses, as well as connecting the role sustainability plays in capturing value, by explaining that sustainability principles support a BV approach for businesses, aiming to capture value for a number of different stakeholders.

However, Elkington et al. (2006) note that businesses tend to struggle to successfully integrate BV in practice. They explain that in order to more successfully create "Value Blends," BV strategies need to be implemented into four main areas of the business: brands, balance sheets, boards, and business models. Typically, most companies incorporate BV strategies in the area of balance sheets, as seen in sustainability reporting and communication, as well as brands, as seen in environmentally and socially-focused marketing strategies. They pinpoint business models, 
specifically the development of new SBMs, as the next step for businesses achieving BV. Additionally, Freudenreich et al. (2019, p. 9) explain that businesses that incorporate BV strategies can provide a "richer basis for developing business models for sustainability."

\section{Designing Sustainable Business Models}

While BV theory provides a framework for how businesses can become more sustainable by valuing environmental, social, and economic return as one, it does not explain how exactly to incorporate this into a business model. However, there have been a variety of management tools developed to design and create business models that apply BV theory. Many of these tools are extensions of Osterwalder and Pigneur's (2010) Business Model Canvas (BMC), which is used to construct, organize, and visualize the design and re-design of business models. The BMC incorporates nine basic building blocks, which help to facilitate how businesses can create, deliver, and capture value.

While the BMC has become a standard for business model development, it only focuses on value creation in the sense of economic value; environmental and social values are not considered. However, given its ease of use and ability to apply to multiple types of businesses, the BMC has been a common foundation for new business model tools that do incorporate sustainability and BV theory (Broman and Robèrt, 2017; Joyce and Paquin, 2016; Kozlowiski, Searcy, \& Bardecki, 2018; Upward, 2013).

One example of a sustainability-oriented extension of the BMC is the Strongly Sustainable Business Model Canvas (SSBMC) developed by Upward (2013). The purpose of the SSBMC is to create and transform existing business models in ways to move toward strategic sustainability. Strategic sustainability is the "intention and action that is understood to be fully contextualized and embedded within ecological, social, and economic dimensions" (Kurucz et al., 2017, p. 190). 
The SSBMC identifies three contexts and four perspectives within each context. The three contexts are the: (a) economy, (b) environment, and (c) society. The four perspectives that need to be considered within each context are: (a) stakeholder, (b) product, learning, and development, (c) process, and (d) measurement. By considering these perspectives and their relationships within each context when developing a business model, Upward (2013) believes a complete SBM is achievable.

Another tool for SBM design is the Framework for Strategic Sustainable Design (FSSD), developed by Broman and Robèrt (2017). The FSSD is a framework created to help businesses by providing specific environmental and social principles of sustainability and guidance on how to achieve those principles (Broman \& Robèrt, 2017).

There are also instances where the BMC can be used to construct a Sustainable Business Model canvas for a specific industry, in order to support entrepreneurs interested in those specific enterprises. One example of this is the reDesign canvas, developed by Kozlowski, Searcy, and Bardecki (2018), which helps entrepreneurs transition to develop sustainable fashion brands. The reDesign canvas is roughly based on the BMC, but uses information from the academic literature, as well as qualitative data from interviews with sustainable fashion entrepreneurs and experts to expand the BMC so to better cater to the sustainable fashion industry.

Another modified canvas, the Lean Canvas, aims to mitigate risk and uncertainty in products, services, or business development in order to avoid any undesired outcomes, such as negative environmental or social externalities (Maurya, 2012). The Lean Canvas stems from the original BMC, but helps entrepreneurs identify the problem and subsequent solution the business model aims to fulfill. The Lean Canvas also helps in identifying the unfair advantage of the 
business model, specifically how the business differentiates itself from competition (Borseman et al., 2016).

Joyce and Paquin (2016) developed a Triple Layered Business Model Canvas (TLBMC), which is the most direct sustainability-oriented extension of Osterwalder and Pigneur's (2010) BMC. The TLBMC adds an environmental and social layer to Osterwalder and Pigneur's (2010) economic-focused BMC. The environmental and social additions are called layers because the building blocks in them correspond perfectly with the original BMC. With all three layers together, the TLBMC is a more holistic tool that businesses can use to visualize their business model and understand how they can develop economic, environmental, and social value. A more thorough description of the TLBMC will be discussed in the Approach/Methods section.

\section{Start-ups and Sustainable Business Models}

As innovation and a SBM are potential requirements for sustainable development, startups play an essential part in achieving sustainability because they play a key role in introducing both these things to society (Hall et al., 2010; Pacheco et al., 2010; Bocken, 2015). The EU (2012, p. 1) states in their Eco-innovation Action Plan that "start-ups can be the ideal incubators for ecoinnovation and can bring to market new, less environmentally damaging products, services, and processes". This is because many of the important decisions regarding the business, including developing the business model, are made in the early stages of a business (Herstatt \& Verworn, 2004; Bocken et al., 2014; Bocken, 2015). Additionally, many of these choices play an important

role in determining the negative effects produced, such as environmental or social externalities, of the business as it grows (Herstatt and Verworn, 2004; Bocken et al., 2014). It may also be harder for larger companies to adopt a sustainable business model once they are well established. Shevchenko et al. (2016) assert that sustainability is important to prioritize in young companies as 
large and powerful companies will have a harder time transitioning due to high costs, entrenched interests, and difficulty to disrupt the status-quo.

\section{Sustainable Start-ups}

Though all are interpretations of the general idea of sustainability, there is a variety of different descriptions of what a start-up needs to have or to do to be considered sustainable. The most broad and all-encompassing characterization is made by Shepherd and Patzelt (2011) who explain that sustainable entrepreneurship needs to preserve nature, ecosystems, and communities, while creating gains for individuals, the economy, and society. Hockerts and Wüstenhagen (2010, p. 482) define sustainable entrepreneurship as "the discovery and exploitation of economic opportunities through the generation of market disequilibria that initiate the transformation of a sector towards an environmentally and socially more sustainable state."

Stubbs (2017, p. 331) explains that sustainable entrepreneurs integrate sustainability goals into their business "because their economic success is strongly associated with their environmental and/or social performance." A successful business would then also contribute to solving environmental and/or social problems as well as making a profit (Stubbs, 2017). While the majority of the literature focuses on the implementation of sustainability in large businesses, an increasing interest in the area of sustainable start-ups and entrepreneurship has been seen with contributions from key researchers (Hockerts \& Wüstenhagen, 2010; Parrish, 2010; Bocken, 2015).

\section{Entrepreneurs}

Research also focusses on the skills and characteristics entrepreneurs need in order to successfully guide a sustainable business. Dentoni et al. (2012) identify seven key competencies required to achieve sustainable development for a business. The seven competencies are: (a) 
systems-thinking competence, (b) foresight-thinking competence, (c) normative competence, (d) embracing diversity and interdisciplinarity, (e) interpersonal competence, (f) action competence, and (g) strategic management. The competencies and descriptions of the competencies as identified by Dentoni et al. (2012) can be seen in Table 1.

\begin{tabular}{|c|c|}
\hline Competencies & Description \\
\hline Systems-thinking competence & $\begin{array}{l}\text { The ability to recognize and analyze relevant systems across domains } \\
\text { (environment, social, and economic) and disciplines (Lans et al., 2014). }\end{array}$ \\
\hline $\begin{array}{l}\text { Embracing diversity and } \\
\text { interdisciplinary }\end{array}$ & $\begin{array}{l}\text { The ability to collaborate between different scientific fields and cultures, as } \\
\text { well as recognizing other viewpoints in decision-making processes regarding } \\
\text { environmental, social, and economical issues. (De Haan, 2006; Ellis \& } \\
\text { Weekes, 2008) }\end{array}$ \\
\hline Foresighted thinking & $\begin{array}{l}\text { The ability to envision the potential long-term impacts of short term } \\
\text { decisions on environmental, social, and economical issues. (Wiek et al., } \\
\text { 2011) }\end{array}$ \\
\hline Normative competence & $\begin{array}{l}\text { The ability to collectively map, specify, apply, reconcile, and negotiate } \\
\text { sustainability values, principles, goals, and target (Gibson, 2006; Grunwald, } \\
\text { 2004; Wiek et al., 2011). }\end{array}$ \\
\hline Action competence & $\begin{array}{l}\text { The ability to involve oneself in responsible actions that contribute to the } \\
\text { goals of sustainability (De Haan, 2006; Ellis \& Weekes, 2008; Mogensen \& } \\
\text { Schnack, 2010; Schnack, 1996) }\end{array}$ \\
\hline Interpersonal competence & $\begin{array}{l}\text { The ability to inspire, facilitate, and enable collaborative sustainability } \\
\text { activities and research (De Haan, 2006; Wiek et al., 2011). }\end{array}$ \\
\hline Strategic management & $\begin{array}{l}\text { The ability to manage projects, implement ideas, strategies, and transitions } \\
\text { towards sustainable development practices (De Haan, 2006; Wiek et al., } \\
\text { 2011). }\end{array}$ \\
\hline
\end{tabular}

Table 1: Seven competencies required by a business to achieve sustainable development

Additionally, Parrish (2010) performed an empirical field study in order to compare four sustainable entrepreneurs design processes of their start-ups. The findings identified five general rules that guide sustainability-driven entrepreneurs. These five rules are: (a) resource perpetuation, (b) benefit stacking, (c) strategic satisficing, (d) qualitative management, and (e) worthy contribution (Parrish, 2010). These five rules and descriptions to guide sustainability-driven entrepreneurs can be seen in Table 2. 


\begin{tabular}{|c|c|}
\hline Rules & Descriptions \\
\hline Resource perpetuation & $\begin{array}{l}\text { Using human and natural resources in a way that } \\
\text { maintains them for the longest time possible. }\end{array}$ \\
\hline Benefit stacking & $\begin{array}{l}\text { Stacking as many benefits as possible onto each } \\
\text { operational activities. }\end{array}$ \\
\hline Strategic satisficing & $\begin{array}{l}\text { Identifying satisfactory outcomes and processes as } \\
\text { decision criteria }\end{array}$ \\
\hline Qualitative management & Decision-making focuses on better rather than more. \\
\hline Worthy contribution & $\begin{array}{l}\text { Allocating benefits of the organization based on the } \\
\text { stakeholders worthiness rather than ones who have the } \\
\text { most control or seniority. }\end{array}$ \\
\hline
\end{tabular}

Table 2: Five general rules that guide sustainability-driven entrepreneurs

\subsection{Sustainability and Venture Capitalism}

Venture capitalists (VCs) have an important role on the success of sustainable start-ups and play a key role in the emergence of businesses. As they decide what types of start-ups receive funding, they can be seen as the "gatekeepers" to new businesses and ideas (Marcus et al., 2013, p. 36). VCs can facilitate increasing start-up growth, value creation, and help to generate more employment and innovation opportunities (Keuschnigg, 2004). Scholars also agree that VCs play the same important role in the case of the development of sustainable start-ups (Bürer \& Wüstenhagen, 2003; Randjelovic et al., 2003; Bocken, 2015).

Researchers have noticed an increase in the support from VCs towards start-ups that display aspects of sustainability (Randjelovic et al., 2003). Boons et al. (2003) agree with this, noting the increasing amount of capital directed toward sustainable innovations. Ethical Markets Media (2018) report in their 2018 Green Transition Scoreboard report that there has been an upward trend in cumulative worldwide private investments and commitments in green technology, totalling US $\$ 9.37$ trillion from 2007 to 2018 , with interest and funding in the latter years nearly doubling that raised in the earlier years. Comparing equal periods over this 10 year range, from 
2007-2012, US $\$ 3.3$ trillion was invested in green technology and US \$6.07 trillion during 20122018 (Ethical Markets Media, 2018).

However, a study by de Lange (2017) which sampled 300 start-ups across thirty cities worldwide in order to examine whether sustainability is rewarded by investors found that investors generally avoid start-ups that incorporate sustainability, specifically environmental sustainability.

The study was conducted by selecting ten start-ups from thirty of the world's major cities that have many start-ups. Of the start-ups chosen for each city, five were purposely chosen for being sustainable, based on self-identifying as sustainable on the start-ups website, the other five startups were randomly sampled in order to represent that non-sustainable firms. The start-ups industry was not considered or noted in the study.

De Lange (2017) found that, generally, investors are more interested in start-ups that are socially responsible, though do not care if they are also environmentally conscious (de Lange, 2017). The author reasons that because of this, investors are not likely to be the driving factor of sustainable venture growth under these conditions. Mrakajic et al. (2019) found similar results; start-ups that provide environmental benefits are not more likely to get VC funding. However, Mrkajic et al. (2019) did find that start-ups that are based on environmental technologies or products and position the business in a green sector are attractive and viewed as reliable by VCs.

\subsection{Sustainability in Sports}

Though sports and sustainability might not seem like an obvious pairing, there has been some research recently dealing with these two topics. A content analysis study by Mallen et al. (2011) examined the extent of environmental sustainability research within sport-related journals. The study found that of 4,639 peer reviewed articles from 21 sport-related journals, only 17 articles $(0.365 \%)$ were directly related to environmental sustainability. 
There is growing acknowledgment of the need for more research on sustainability in sports and the application of it, including the recognition by the United Nations (U.N.) at their Framework Convention on Climate Change (UNFCCC, 2017) of the advantage and duty of sport's role in promoting sustainable behaviour of fans (Ottman, 2017; Sartore-Baldwin et al., 2017; SartoreBaldwin \& McCullough, 2018; Trail \& McCullough, 2018; Trail \& McCullough, 2019).

\section{Environmental Issues in Sports}

Researchers note that the environmental footprint related to sports is quite immense, yet goes relatively unnoticed (Thibault, 2009; Pfahl, 2010; Inoue \& Kent, 2012). This is largely due to the fact that the nature of sport is highly dependent on the environment, as many sports are played outdoors. Additionally, the large number of sporting events held throughout the world and their various externalities contribute to the environmental footprint of sports (Thibault, 2009; McCullough et al., 2016). While there has been an uptick in the area of environmental sustainability in sports, most research tends to focus on facilities and event management, influencing the environmental behaviours of fans, and environmental management within teams and leagues.

Environmental issues have become an important part of strategy and actions by sports organizations and personnel (Babiak \& Wolfe, 2009; Thibault 2009; Pfahl 2011; Trendafilova et al., 2013). Environmental sustainability has been recognized to offer several competitive benefits, such as increased goodwill, fan identification, and a competitive advantage (McCullough \& Cunningham, 2010; Kellison \& Hong, 2015). Consumer awareness about the need for sustainability programs has led sports organizations to put higher emphasis on the environment. Organizers of sporting events have begun increasingly focusing on ways to reduce the environmental impact of their event (Trail \& McCullough, 2019). These initiatives can range from 
basic recycling and waste diversion programs to more advanced programs focusing on offsetting carbon emissions (McCullough et al., 2016; Trail \& McCullough, 2019). For example, prior to the 2008 Summer Olympic Games in Beijing, over US $\$ 17$ billion was spent to address environmental issues regarding the event (United Nations Environment Programme, 2009). These measures mainly focused on improving air quality in Beijing in the surrounding areas, by focusing on implementing pollution control policies for the increased industrial and transportation demand of the event (Huijuan et al., 2013).

Sport-related companies have realized the need to adopt sustainability practices as well. Many sports clothing and equipment companies, such as NIKE and Adidas, have been integrating sustainability into their brand and making bold environmental and social commitments. In NIKE's 2014/2015 Sustainable Business Report, NIKE introduced their "Environmental Moonshot," which is their goal to double their business with half the environmental impact as their current standards (NIKE, 2019) NIKE is focusing on reducing their carbon emissions, water usage, and hazardous chemical usage in order to reach this (NIKE, 2019). Additionally, Adidas recently released a line of athletic clothing and shoes made out of plastic trash collected from beaches and coastal communities (Adidas, 2017).

\section{Social Issues in Sports}

Sports have had a historically large and important role in social issues as well. The cultural foundations embedded within sports allow it to shape and be shaped by social issues (McCullough et al., 2016). Throughout history, sports have played an important part in issues of race, gender, and injustices. Jesse Owens, Jackie Robinson, Serena Williams and other black athletes broke racial barriers and paved the way for all aspiring athletes around the world. Billie Jean King, Megan Rapinoe, and Manon Rhéaume proved sports also belonged to women, challenging 
prejudices and stereotypes. Repeatedly, sports have been shown to be a reflection and facilitator of social change throughout the world (McCullough et al., 2016). Additionally, sports have offered many athletes, teams, and leagues the opportunity to create programs and foundations aimed at helping various social issues. A study by Babiak et al. (2012) measured the scope and presence of charitable foundations established by athletes in the United States and found that there were 1,122 established foundations in 2012.

While there has been an increase in the presence of sustainability in the sports industry, there is still a lack of research about the innovation of sport-related products and services that incorporate sustainability aspects. Ratten (2016) notes how surprising it is that there is a lack of general literature about the role of innovation in sport, given that sport is an extremely innovative industry. Ratten (2016) refers to the diverse product offerings and unique service attributes that require a distinct management approach. As it is clear that sport is not immune to the pressures of climate change and social issues, there is a need to understand how the sports industry can contribute to the sustainable innovation of products and services.

\subsection{Sustainability and Software}

ICT can be viewed as a double-edged sword when examining its energy usage. On one hand, it can be considered a more sustainable option, as it reduces the need for physical counterparts, thus using less physical materials and resources (Naumann et al., 2011). On the other hand, with the increasing technology related functions and use of data centres in society, ICT's energy demand is rising every year (Naumann et al., 2011). A study done in April 2007 calculated that $2 \%$ of global carbon emissions are directly due to ICT systems; this is equivalent to the entire aviation industry (Rivoire et al., 2007). However, Ericsson's (2019) Sustainability and Corporate Responsibility Report shows that ICT solutions can actually help to reduce global greenhouse gas 
emissions by up to $15 \%$ in other industries by 2030 . Additionally, as software has become largely ingrained in many different industries, its energy efficiency and environmental impact are becoming increasingly important (Kocak, 2013).

Cloud computing has given rise to increased energy consumption, and thus carbon emissions (Garg and Buyya, 2012). However, some studies show that cloud computing can make traditional data centres more energy efficient, especially when technologies such as resource virtualization and workload consolidation are used (Accenture Microsoft Report, 2012). Additionally, while cloud data centre energy demand has increased slightly since 2010, this growth seems to be decoupled from the growth in the cloud data centre compute instances, suggesting the increased efficiency abilities of cloud data centres (Masanet et al., 2020). While cloud computing does result in increased efficiency, coal-fired power generation is still the main source for electricity generation worldwide at $38 \%$ in 2018 (IEA, 2019). IEA (2019) also report that global coal power generation rose from 2017 to 2018 and demand is expected to be stable through 2023 . However, the amount of coal-fired power used in the supply-mix for electricity varies significantly with location (Dolter \& Rivers, 2018). For example, in Ontario, Canada does not use any coalfired power generation in its electricity supply (IESO, 2019), while in Saskatchewan, Canada, coal-fired power plants constitute $29 \%$ of the electricity supply (SaskPower, 2019).

While energy reduction may be the main focus in the environmental impacts of ICT, Oyedeji et al. (2018) reason that the focus should not be limited to just energy; considering other ICT environmental measures such as electronic waste management and the environmental impacts of recycling computing gear are also important. There are also potential social issues in the industry as well, including ethical issues such as data privacy and consumers' rights (Grigore et al., 2017; Ericsson, 2019). 
As the ICT industry grows and environmental and social issues arise, it raises the question of how ICT companies should act in order to be corporately responsible. Grigore et al. (2017) discuss different approaches of what it means to be a responsible corporation in the ICT industry, specifically highlighting new areas of responsibility and potential issue areas. Some of the potential areas that could cause concern include transparency of digital communication strategies, information security, privacy, and data collection storage (Grigore et al., 2017).

Digitization, which is the use of digital information and communication technologies, has also been discussed as being both a barrier to and driver of sustainable development. Van der Velden (2018) finds that digital technologies can be enabling in the endeavor towards sustainable development, primarily through a decoupling of economic growth and environmental degradation, if possible. While there are no set agendas or solutions to sustainability challenges within digital technologies, van der Velden (2018, p.170) suggests digital technology businesses need to transition from minimizing environmental and social negative effects to instead "generating life and regenerating the planet." 


\subsection{METHOD}

Qualitative case study research, through conducting informal interviews and a set of follow-up questions, was the primary method for this project. The research was carried out with start-ups formerly in the Future of Sport Lab (FSL) Incubator. The FSL is a collaborative lab for sport innovation and research between Ryerson University and Maple Leafs Sports and Entertainment Ltd. (MLSE). The FSL Incubator empowers start-ups, providing research and facilitating growth. Six sport-related start-ups graduated from the FSL Incubator in the summer of 2019. Three of them, all software-based start-ups, are the focus of this project. The three start-ups are:

- Performance Phenomics (PP), which conducts brain-imaging assessments to offer scientific insight into athletic performance and proper recovery and is based in Toronto, Ontario.

- Rival.ai (R.ai), which is an eSports company using artificial intelligence to provide scouting reports for teams, trainers, as well as the online video gaming community and is based in Toronto, Ontario.

- SkillShark (SS) offers an online platform for coaches to rank and evaluate athletes across multiple sports and is based in Saskatoon, Saskatchewan.

The qualitative case study research approach was chosen due to the complex nature of this type of data. According to Patton (2002), this approach is best suited for identifying themes, patterns, concepts, and insights in qualitative data. The primary data used for this project were collected through interviews; these interviews were used to ascertain the current level of social and environmental activities within the start-ups themselves, as well as any themes or patterns among the three start-ups regarding incorporating social and environmental activities. The 
interviews of each start-up were structured around the Triple Layered Business Model Canvas (TLBMC) developed by Joyce and Paquin (2016).

The TLBMC is an extension of Osterwalder and Pigneur (2010) Business Model Canvas (BMC). The BMC is a template for developing new or revising existing business models. It covers the four main segments of business: (a) infrastructure, (b) value offer, (c) customers, and (d) financial viability (Osterwalder and Pigneur, 2010; França et al., 2017). Partners, activities, and resources make up the infrastructure of the business. Value proposition, the product or service that the business offers to meet consumer needs, corresponds to the value offer of the business. Customer relationship, channels, and customer segments make up the customer segment and the costs and revenues depict the financial viability of the business. A template of Osterwalder and Pigneur's (2010) Business Model Canvas with general descriptions of each building block can be seen in Figure 1.

\begin{tabular}{|c|c|c|c|c|c|}
\hline \multirow[t]{2}{*}{$\begin{array}{l}\text { Partners } \\
\text { Describes the network } \\
\text { of partners and } \\
\text { suppliers that make the } \\
\text { business model work }\end{array}$} & $\begin{array}{l}\text { Activities } \\
\text { Describes the most } \\
\text { important things a } \\
\text { company should do to } \\
\text { make its business } \\
\text { model work } \\
\text { successfully }\end{array}$ & \multirow{2}{*}{\multicolumn{2}{|c|}{$\begin{array}{l}\text { Value } \\
\text { Proposition } \\
\text { Describes the bundle } \\
\text { of products and } \\
\text { services that create } \\
\text { value for a specific } \\
\text { customer segment }\end{array}$}} & $\begin{array}{l}\text { Customer } \\
\text { Relationship } \\
\text { Describes the type of } \\
\text { relationships a } \\
\text { company establishes } \\
\text { with specific customer } \\
\text { segments. }\end{array}$ & \multirow{2}{*}{$\begin{array}{l}\text { Customer } \\
\text { Segments } \\
\text { Defines the different } \\
\text { groups of people or } \\
\text { organizations an } \\
\text { enterprise aims to } \\
\text { reach and serve }\end{array}$} \\
\hline & $\begin{array}{l}\text { Resources } \\
\text { Describes the most } \\
\text { important assets } \\
\text { required to make a } \\
\text { business model work }\end{array}$ & & & $\begin{array}{l}\text { Channels } \\
\text { Describes how a } \\
\text { company } \\
\text { communicates with and } \\
\text { reaches its Customer } \\
\text { Segments to delver a } \\
\text { Value Proposition }\end{array}$ & \\
\hline \multicolumn{3}{|c|}{$\begin{array}{l}\text { Costs } \\
s \text { Describes all costs incurred to operate a business } \\
\text { model }\end{array}$} & \multicolumn{3}{|c|}{$\begin{array}{l}\text { Revenues } \\
\text { \$ Represents the cash a company generates from } \\
\text { each Customer Segment }\end{array}$} \\
\hline
\end{tabular}

Figure 1: Osterwalder and Pigneur's (2010) Business Model Canvas

The TLBMC adds environmental and social layers to the original economic layer of the BMC. By adding a distinct environmental and social layer, the TLBMC is useful in helping 
businesses understand the individual social and environmental impacts, benefits, and potential areas of value creation. Additionally, as the layers vertically align with each other, connections between each layer can be drawn to help support the triple bottom line perspective and understand how the business can generate multiple types of value (Joyce \& Paquin, 2016). Joyce and Paquin (2016) describe these two abilities as "horizontal coherence," and "vertical coherence" (p. 2); these coherences can be seen in Figure 2.

\section{Horizontal coherence}

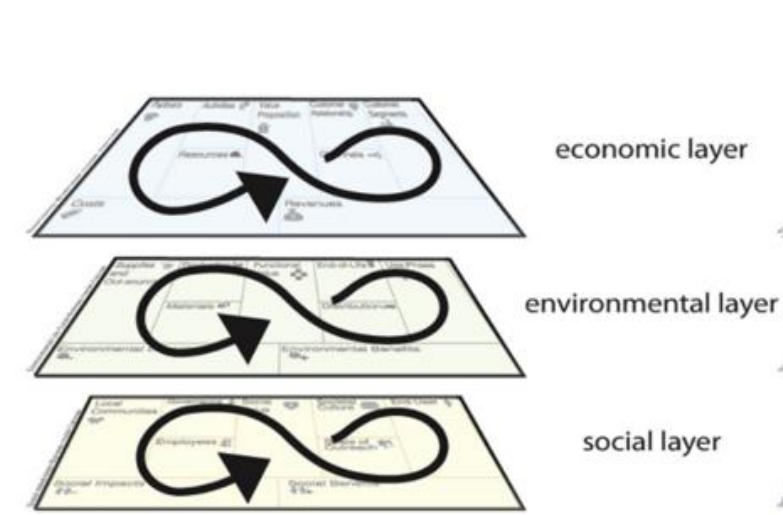

Figure 2: The horizontal coherence and vertical coherence of the TLBMC (Joyce \& Paquin, 2016)
Vertical coherence
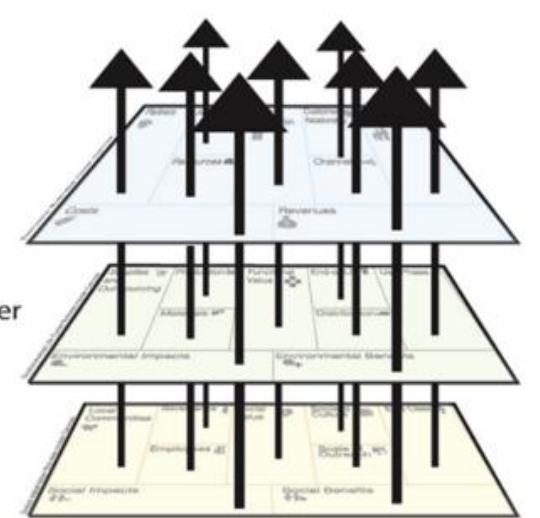

The environmental layer of the TLBMC is founded around a life cycle perspective of the environmental impact of a product or service. The life cycle perspective stems from Life Cycle Assessments, which are used to measure the total environmental impact of a product or service across its entire life, from raw-material extraction to disposal (Joyce and Paquin, 2016). Along with helping to understand all the environmental impacts of a product or service over its lifespan, the environmental layer helps to understand how businesses can generate more environmental benefits than environmental impacts. Breaking up the layer into nine building blocks, like the BMC, can help businesses visualize and understand where environmental impacts lie. Thus, helping businesses identify potential opportunities to create environmental value (Joyce \& Paquin, 2016). Figure 3 shows the Environmental Life Cycle Business Model Canvas and the general 
descriptions of the building blocks (Joyce and Paquin, 2016), followed by a brief explanation of each building block with some examples relevant to software-related businesses.

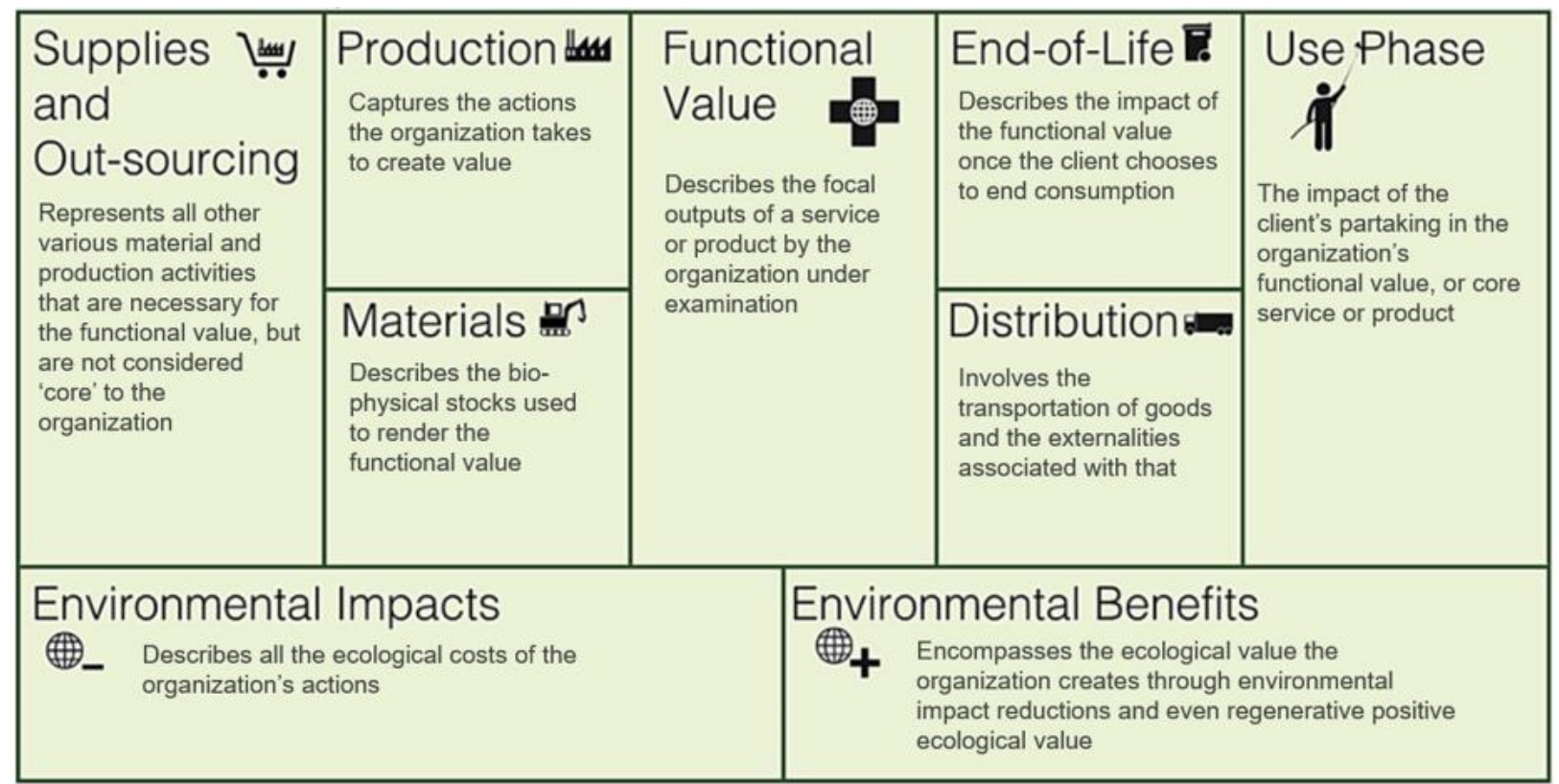

Figure 3: The Environmental Life Cycle Business Model Canvas (Joyce \& Paguin, 2016)

The functional value is the focal output of a service by the business and is used to examine what the business's service performance is over a specific timeframe. Materials are the key biophysical stocks needed to create functional value, for a service company, these can include materials such as building infrastructure, information technology, computers, and office buildings. Production refers to the activities that are key to creating functional value for the business, for a service provider, these could include activities such as running IT infrastructure, using office space, and software development. Supplies and Outsourcing include materials and production that the business use but are not considered "core" to support the business's functional value creation, such as water and energy usage.

Distribution represents the means by which the business provides access of the functional value to the consumer, for software-related business, Distribution focuses on how the software is made available to the consumer. Use Phase focuses on how the consumer partakes in using the 
functional value, for software-related businesses, examples include the material resource, such as computers, and energy requirements needed for use of the product/service. End-of-Life is when the user chooses to end the consumption of the functional value, the business can explore ways to extend its responsibility of the materials used to create the functional value.

Environmental Impacts cover all of the ecological costs that occur as a result of a business's actions, such as emissions, water usage, and energy consumption. Environmental Benefits cover all of the ecological value the business creates as a result of both environmental impact reductions and creating positive environmental value, examples include using energy efficient machines, prioritizing renewable resources, and limiting waste.

The social layer of the TLBMC is built on a stakeholder management approach to explore a businesses' social impact. Like the environmental layer, the social layer is sectioned into nine building blocks that correspond with Osterwalder and Pigneur's (2010) BMC. The social layer is used to identify and incorporate the interests of a business's stakeholders, rather than simply seeking to maximize gains for the business itself. Figure 4 shows the Social Stakeholder Business Model Canvas and general descriptions of the building blocks (Joyce and Paquin, 2016) followed by a brief explanation of each building block with some examples relevant to a software-related business.

The social value describes the business's mission, which can include creating benefits for the business's stakeholders and society more broadly. Employees describes the role employees have in the business, including the number and type of employees, demographics, as well as any employee-oriented programs the business has that contributes to the long-term viability and success of the employees. Governance describes the organization's structure and decision-making 
policy, including which stakeholders an organization views as most important, examples of different

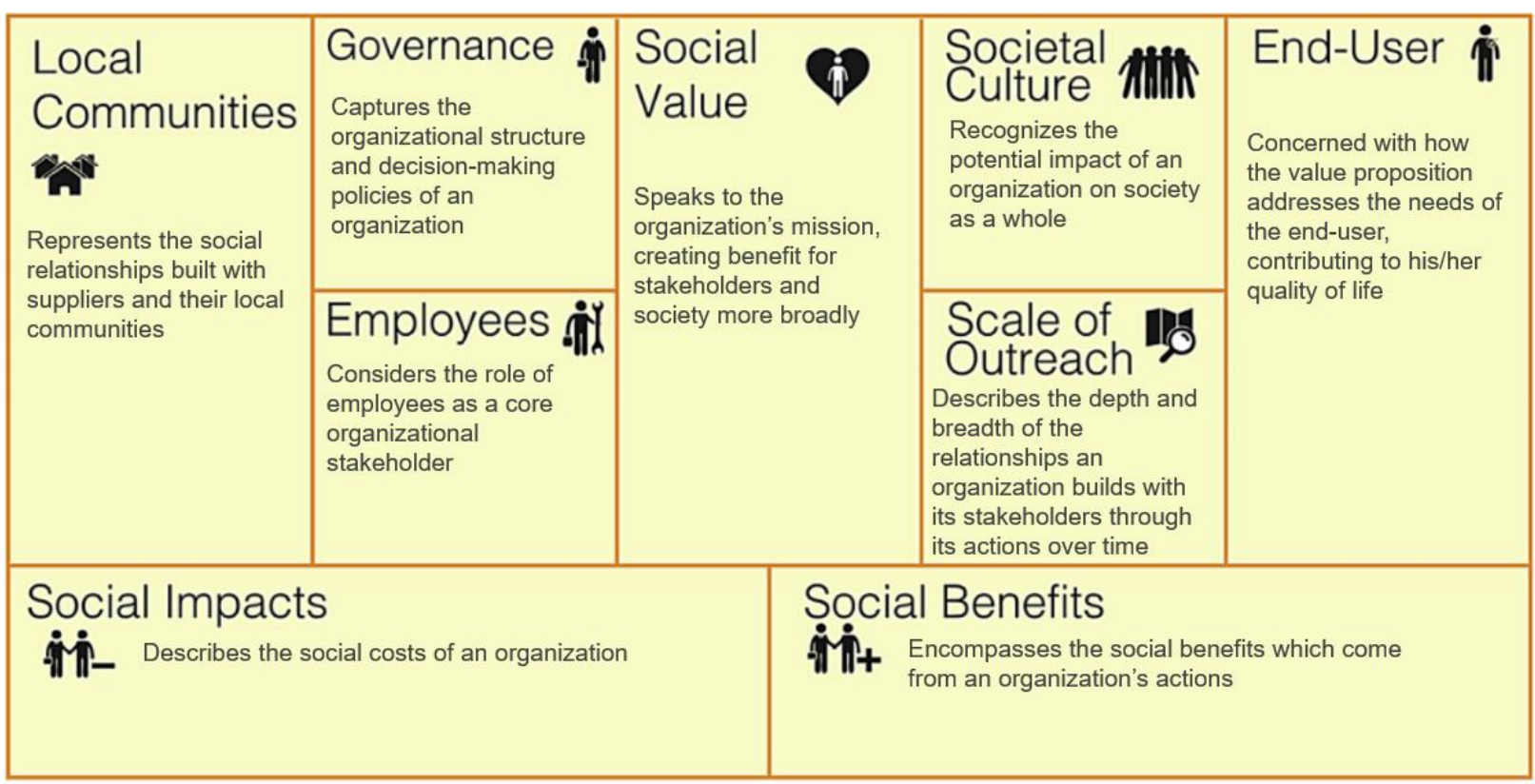

Figure 4: The Social Stakeholder Business Model Canvas (Joyce \& Paquin, 2016)

governance structures include ownership, such as privately owned for-profit versus publicly traded for-profit, internal organization structures, and decision-making policies within the business. Local Communities focus on the relationships the business has with its suppliers and local communities, specifically how a business manages those relationships and if a business considers communities and suppliers as stakeholders.

The social value describes the business's mission, which can include creating benefits for the business's stakeholders and society more broadly. Employees describes the role employees have in the business, including the number and type of employees, demographics, as well as any employee-oriented programs the business has that contributes to the long-term viability and success of the employees. Governance describes the organization's structure and decision-making policy, including which stakeholders an organization views as most important, examples of different governance structures include ownership, such as privately owned for-profit versus 
publicly traded for-profit, internal organization structures, and decision-making policies within the business. Local Communities focus on the relationships the business has with its suppliers and local communities, specifically how a business manages those relationships and if a business considers communities and suppliers as stakeholders.

Societal Culture recognizes the potential a business has to influence society, specifically how it can positively influence society through its actions. Scale of Outreach describes the depth and breadth a business has with its stakeholders, examples can include developing long-term relationships with stakeholders and the outreach a business may have with its local community. End-User focuses on how the business contributes to the quality of life of the End-User. Additionally, it is important to note the End-User may not always be the customer, meaning businesses need to consider how the product/service contributes to the quality of life of both the customer and End-User.

Social Impacts covers all the social costs of a business, including measures such as working hours, cultural heritage, health and safety, community engagement, fair competition, and intellectual property rights. However, as there are a growing number of social impact measures, there may be different measures to consider for different businesses. Social Benefits covers all of the positive social value created by a business, as with Social Impacts, Social Benefits measures are specific to the nature of the business.

\subsection{Ethics}

This study was submitted for review to the Ryerson Ethics Board and was deemed to not require review. In any case, the individuals that took part in the study gave consent to participate and were ensured that all questions and participation were voluntary. The interviews were recorded using a voice recorder and then transcribed. The recordings were digitally encrypted so to only be 
accessed by the main researcher. Once the information needed was extracted, the recordings were destroyed.

\subsection{Interviews}

The interviews consisted of an open discussion with the entrepreneurs, who are the solefounders and owners of the start-ups, about how their current business model fits into the TLBMC. As the three start-ups have already been exposed to the BMC from working in the FSL, the TLBMC was anticipated to be easy for them to use and understand, as the additional layers correlate perfectly with the original canvas. Questions for the interviews were developed based on the environmental and social layers only of the TLBMC. As the objective of this project is to understand the current environmental and social considerations of entrepreneurs, questions relating to the economic layer were not asked. Two questions were asked that related to each of the building blocks of the environmental and social layer. An open discussion regarding the entrepreneurs' attitudes and opinions of each building block stemmed from these questions. There were also a set of general questions asked at the end of each interview. The set of questions asked in each interview can be seen in Appendix A: Interview Questions.

After the interviews were completed and analyzed, a set of follow-up questions were developed. The follow-up questions were developed to expand on some of the gaps from the interviews, specifically the potential negative social and environmental effects of the start-ups. The follow-up questions focus primarily on the environmental and social effects of software companies. The follow-up questions were e-mailed to the start-ups approximately three months after the interview. The responses to the follow-up questions were also received through e-mail. The follow-up questions can be seen in Appendix B: Follow-up Questions. 
The primary data used for this project were collected through interviews and subsequent follow-up questions with the entrepreneurs of the three start-ups listed above. The interviews were audio recorded and transcribed after to develop an accurate interview report. Interviews took place both in person and via video chat, and lasted approximately one to two hours. The follow-up questions were e-mailed to each of the start-ups, with the option to discuss them over the phone, or simply respond via e-mail. Two of the start-ups answered the follow-up questions, both via email response. The third start-up, SS, did not respond to three e-mail requests to answer the followup questions and follow-up in person was unreasonable due to distance. The COVID-19 pandemic, which began affecting North America when the follow-up questions were being e-mailed, may have impacted the ability for the start-up to respond. This may be because of the additional stress small businesses were under during the pandemic, especially so given SS's main users are youth sports organizations, which were halted worldwide as a result of COVID-19.

\subsection{Analysis}

The information from the start-ups, consisting of their interview responses and their followup question answers, constitute the basis for analysis. The interview responses were segmented into their corresponding social or environmental building blocks to illustrate how the entrepreneurs believe their start-ups relate to the environmental and social layer of the TLBMC. Each start-up's responses are then analyzed in order to identify what current and potential future environmental and social considerations the start-ups have compared to what environmental and social considerations should be according to the TLBMC (Joyce and Paquin, 2016). The entrepreneur's attitudes towards sustainability in general and opinions on VCs attitudes towards sustainability are also analyzed. 


\subsection{RESULTS}

This section is divided into an overview, based on their interview responses, of how each of the three entrepreneurs described their start-ups in respect to the environmental and social layers of the TLBMC. Each section starts with a brief description of the start-up's product or service followed by a summary of how the entrepreneur described their start-up in relation to the environmental and social building blocks. The summaries are presented in a model similar to the environmental and social layer of the TLBMC. There is also a summary of general environmental and social questions that were asked during the interview that do not fit into the TLBMC. This section also includes a brief summary of the responses to the follow-up questions from the entrepreneurs from PP and R.ai. SS did not respond to the follow-up questions. The summaries are listed by the entrepreneur's responses to each of the six questions.

\subsection{Performance Phenomics}

Performance Phenomics (PP) uses an algorithm to create suggestive brain health reports based on magnetic resonance imaging (MRI) scans. PP's current focus is on stroke and concussion patients. Its main output, a report, details patients' outcomes and predicted recovery. As the entrepreneur's goal is to become part of the standard procedure for stroke and concussion protocol, PP is currently undergoing studies in order to be approved by Health Canada and the U.S. Food and Drug Administration (FDA). PP's Environmental Layer can be seen in Figure 5 and its Social Layer can be seen in Figure 6.

Environmental General. When asked how having environmental considerations in a business model could affect receiving funding from venture capitalists, the entrepreneur stated that there is now an "extreme movement towards ESG (environmental, social, and governance) focus from investors." The entrepreneur believes there is more awareness and everyone wants to know 
what the global impacts of a company are, not only how it is going to make money. However, the entrepreneur did admit that these beliefs are more anecdotal than anything, but does feel it has been a hot topic as of late.

Social General. The entrepreneur believes that having social considerations in the business model can help receive funding from VCs, especially with its product because most people know someone who has been affected by a stroke or concussion.

\section{Follow-Up Responses}

Below are the summaries of the entrepreneur from PP's responses to the six follow-up questions.

1. Since the initial interview, the entrepreneur has not encountered any further potential negative social or environmental effects.

2. The entrepreneur believes that corporate social responsibility for a digital company is the most difficult, yet likely the most important task of the business. The entrepreneur sees corporate social responsibility at PP in two specific areas: privacy protection and data management. PP takes the approach that "doing well as a company comes from doing good by [PP's] patients."

3. Again, the entrepreneur believes they can "do-good" by providing the best care possible to their patients. The entrepreneur also states that "the movement into Impact Investing will drive dollars away from companies that have a mindset of profit at all costs. This will be the rising tide for the social and responsible companies."

4. PP has not spent much time looking at emissions of the company. However, as a company split between two cities, PP tries to limit travel by using video technologies to communicate as much as possible. 


\section{Environmental Layer}

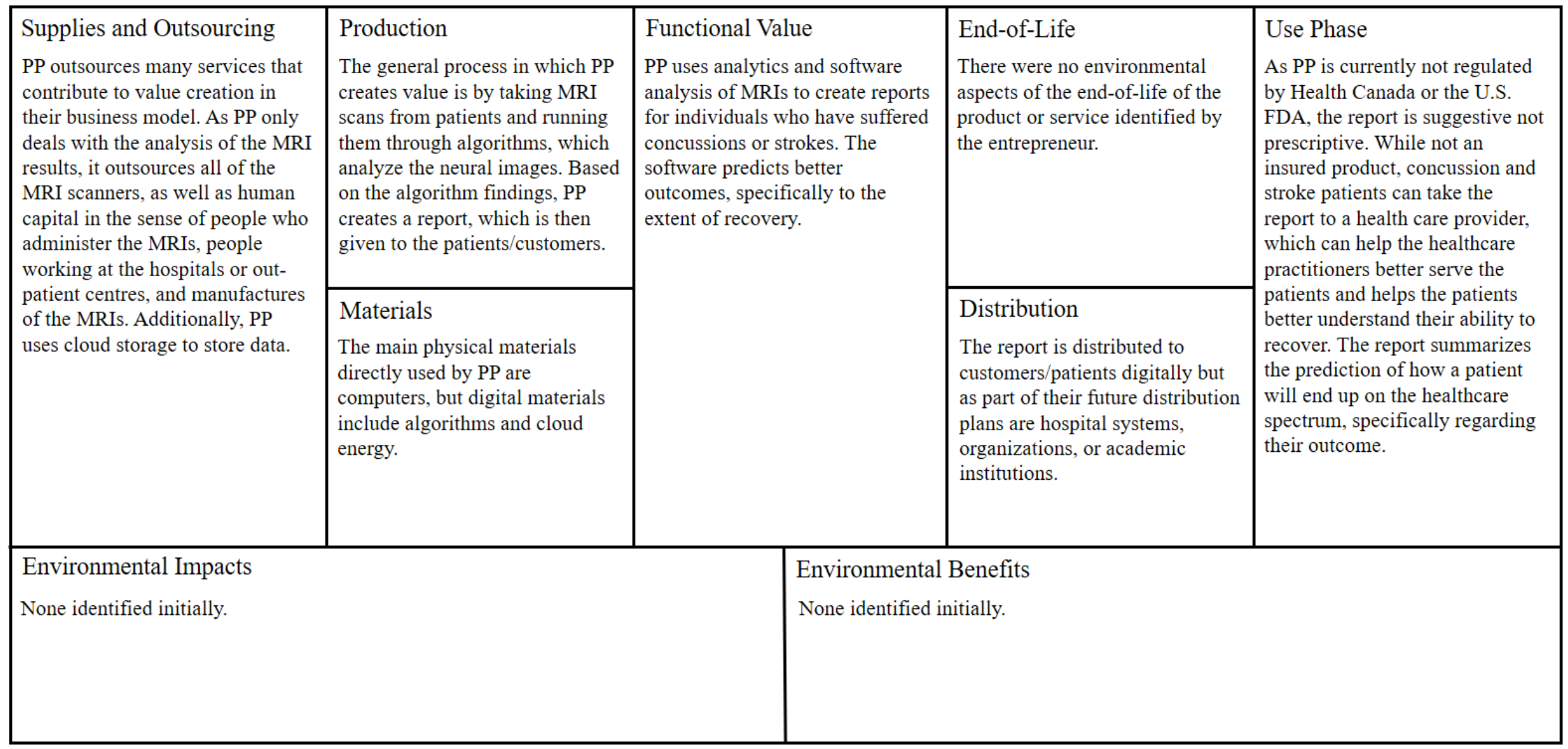

Figure 5: Performance Phenomics’ Environmental Layer 


\section{Social Layer}

\begin{tabular}{|c|c|c|c|c|c|}
\hline \multirow{2}{*}{$\begin{array}{l}\text { Local Communities } \\
\text { PP has no current partnership, but } \\
\text { the entrepreneur hopes to } \\
\text { eventually partner with sports } \\
\text { leagues, the military, and/or the } \\
\text { stroke community. PP manages } \\
\text { relationships with people at } \\
\text { hospital systems, medical centres, } \\
\text { MRI manufacturers, and } \\
\text { academic institutions in order to } \\
\text { administer the MRIs to patients. }\end{array}$} & $\begin{array}{l}\text { Governance } \\
\text { PP currently has an internal } \\
\text { board of directors that consists of } \\
\text { the CEO, co-founder, and lead } \\
\text { investor. PP is a privately owned } \\
\text { for-profit business. }\end{array}$ & \multirow{2}{*}{\multicolumn{2}{|c|}{$\begin{array}{l}\text { Social Value } \\
\text { PP's social value is through } \\
\text { providing accuracy and outcomes } \\
\text { to stroke and concussion patients. } \\
\text { The entrepreneur believes PP is } \\
\text { contributing to helping patients } \\
\text { receive the best outcome and } \\
\text { helping physicians give the best } \\
\text { line of care possible. }\end{array}$}} & $\begin{array}{l}\text { Societal Culture } \\
\text { The entrepreneur believes PP can } \\
\text { contribute to societal culture } \\
\text { through the "democratization of } \\
\text { healthcare" from a neurological } \\
\text { side, meaning everyone goes } \\
\text { through the same standard stroke } \\
\text { and concussion procedure. }\end{array}$ & \multirow{2}{*}{$\begin{array}{l}\text { End-User } \\
\text { The current structure of the } \\
\text { report that is released to the } \\
\text { patient is based on severity of } \\
\text { injury, location of the injury, } \\
\text { and what the exposure to injury } \\
\text { has been. Once the report is sent } \\
\text { to the patient, PP only keeps the } \\
\text { aggregate, anonymized data. PP } \\
\text { is Personal Health Information } \\
\text { Protection Act (Ontario) and } \\
\text { Health Insurance Portability and } \\
\text { Accountability Act (U.S.) } \\
\text { compliant. }\end{array}$} \\
\hline & $\begin{array}{l}\text { Employees } \\
\text { PP has six to seven full-time } \\
\text { employees, including a } \\
\text { neuroscientist, a computer } \\
\text { scientist, a bioinformatician, an } \\
\text { engineer, a neurosurgeon, and } \\
\text { one businessperson (the } \\
\text { entrepreneur). The entrepreneur } \\
\text { expects PP to grow to around } \\
\text { twelve full time employees by } \\
\text { the year } 2021 \text {. }\end{array}$ & & & $\begin{array}{l}\text { Scale of Outreach } \\
\text { PP manages relationships with } \\
\text { "point people" at different } \\
\text { hospital systems based on } \\
\text { geography, who help set up } \\
\text { appointments for patients. The } \\
\text { entrepreneur believes the } \\
\text { algorithm is a platform } \\
\text { technology, meaning it has } \\
\text { potential to be used for other } \\
\text { neuro-degenerative diseases. }\end{array}$ & \\
\hline \multirow{2}{*}{\multicolumn{3}{|c|}{$\begin{array}{l}\text { Social Impacts } \\
\text { The entrepreneur believes that there are no negative social impacts as a result of PP. }\end{array}$}} & \multicolumn{3}{|l|}{ Social Benefits } \\
\hline & & & \multicolumn{3}{|c|}{$\begin{array}{l}\text { PP's main social benefit is through the democratization of healthcare from a } \\
\text { neurological side. PP is doing this through quantifying neurological health and } \\
\text { neurological performance to better serve individuals who have suffered concussions and } \\
\text { strokes. Additionally, by making concussion and stroke protocols MRI based, PP } \\
\text { eliminates the use of a CT scan, which emits radiation to the individual. Thus, patients } \\
\text { are not exposed to radiation, so could potentially be better for patients in the long term. } \\
\text { From the overall discussion, it is clear that PP is very passionate about helping patients } \\
\text { and the entrepreneur believes one of the benefits about working in healthcare is that } \\
\text { when a product is needed, the solution is helping to solve a real problem someone is } \\
\text { suffering from. }\end{array}$} \\
\hline
\end{tabular}

Figure 6: Performance Phenomics' Social Layer 
5. The entrepreneur does find the fact that coal constitutes the majority of the world's electricity supply alarming.

6. The entrepreneur believes that ICT industry is a driver for sustainable development through allowing for more productive and remote work; therefore limiting the negative effect travel has on the environment. The entrepreneur states that "travel is a significant contributor to the environmental issues globally" and thinks ICT "may help on a macro level."

\subsection{Rival.ai}

Rival.ai (R.ai) is an Esports company that uses artificial intelligence (AI) to sell video game data to casinos. The AI watches video game matches and provides first-party data based on the action on screen. The casinos use R.ai's data to make probabilities for future matches. Rival.ai's Environmental Layer can be seen in Figure 7 and its Social Layer can be seen in Figure 8.

Environmental General. The entrepreneur believes that the main environmental component that is most important to R.ai is energy usage. While discussing the environmental footprint of technology companies, the entrepreneur explained that there are always things that can be done to further minimize an environmental footprint. The entrepreneur identified how servers are functioned, operated, and what is done in the physical office as the biggest factors to reduce an environmental footprint in a technology company. However, the entrepreneur believes that they have a pretty small footprint already. In terms of being less wasteful in the office, the entrepreneur believes that if businesses start with that mentality, it is much easier to implement, because people's habits do not have to be changed later on, which is the approach R.ai has taken with their office operation. The entrepreneur also believes that cloud computing is going to have the biggest positive impact on the environment through energy efficiency. The entrepreneur explained that compared to five years ago, where everyone had their own servers running big machines, cloud 
computing offers the ability for hundreds of clients to rent a cloud server as a virtual machine, making it much more efficient by using less electricity and fewer computers. The entrepreneur also believes that in terms of video gaming, cloud gaming is going to become popular, which also be beneficial to the environment. With cloud gaming, games can just be played through a television, thus not requiring a console, therefore reducing the need for producing materials and consuming electricity.

Environmental Considerations in VC. Asked if having environmental considerations in its business model could play a role in receiving funding from VCs, the entrepreneur stated that "VCs do not care." The entrepreneur explained they have dealt with a lot of VCs and none ever asked about their environmental impact or having environmental considerations in their business model. The entrepreneur does not believe it could even be a differentiating factor for VCs. The entrepreneur did reason that having environmental considerations in R.ai's business model could potentially benefit it by receiving some kind of government grant or R\&D money. The entrepreneur explained that if R.ai was an environmental company producing something along the lines of sustainability, then maybe that would be part of its narrative, but as a video game company, dealing with AI, selling data to casinos, no one expects or asks that of it.

Social General. The entrepreneur believes that the main social aspect that is most important to R.ai is empowering and educating people, as well as giving job opportunities to interns and students. Asked if VCs care about having social considerations in their business model could play a role in receiving funding, the entrepreneur stated that the only thing VCs care about is their return on investment. The entrepreneur admitted he has a pessimistic view of VCs, after meeting with 40-50; none ever asked about R.ai's hiring policy, social influence, or sustainability or environmental footprints, all they care about is how much money R.ai can make them (the VC). 


\section{Follow-up Responses}

Below are the summaries of the entrepreneur from R.ai's responses to the six follow-up questions.

1. In addition to R.ai's environmental impacts discussed in the initial interview, the entrepreneur believes that R.ai could help reduce carbon emissions of video game players through reducing travelling. As R.ai's AI can evaluate a player's performance remotely, it eliminates the need for players to travel to local tournaments in order to be evaluated in person.

2. The entrepreneur admits it is difficult to be a corporate responsible digital company because the business is so reliant on larger systems, like servers, which are out of the company's control. The entrepreneur reasons that once a "green, renewable energy sourced server company comes to market then the choice of who [R.ai] buy[s] services from will put the power of choice back in [R.ai's] hands."

3. The entrepreneur believes it is everyone's responsibility to do good, but the limitations and opportunities to do so ranges dramatically in technology. The entrepreneur admits that "while there are direct ways [R.ai] can do good for people, it is less prevalent with the environment." The entrepreneur explains that at the end of the day, R.ai needs to make a profit. Investors, financiers, clients, and customers do not prioritize the environment as much as they should, though the entrepreneur believes that is slowly changing. The entrepreneur believes that if the government incentivized the business to choose greener solutions, it may do more.

4. The entrepreneur states that if there were green solutions available, then a choice would have to be made by technology companies on who to partner with. However, aside from recycling office paper, reducing plane travel, and giving staff TTC passes, the entrepreneur does not believe much more can be done by R.ai. 


\section{Social Layer}

\begin{tabular}{|c|c|c|c|c|c|}
\hline \multirow[t]{2}{*}{$\begin{array}{l}\text { Local Communities } \\
\text { While R.ai is not currently a part } \\
\text { of any specific video game } \\
\text { association, moving forward, the } \\
\text { entrepreneur believes that they } \\
\text { will probably join one. R.ai has } \\
\text { participated in outreach to various } \\
\text { school teams in their local } \\
\text { community as well as local } \\
\text { tournament organizations. }\end{array}$} & $\begin{array}{l}\text { Governance } \\
\text { R.ai was recently bought out by } \\
\text { Wondr Gaming, an esports } \\
\text { acquisition fund. The entrepreneur } \\
\text { is still the current CEO and runs the } \\
\text { office and team, but Wondr Gaming } \\
\text { makes the bigger decisions. The } \\
\text { entrepreneur believes Wondr } \\
\text { Gaming plans on going IPO some } \\
\text { time in } 2020 \text { and he will be replaced } \\
\text { as CEO sometime after that. }\end{array}$ & \multirow{2}{*}{\multicolumn{2}{|c|}{$\begin{array}{l}\text { Social Value } \\
\text { The social value that R.ai brings } \\
\text { is by providing the highest } \\
\text { quality data in the video game } \\
\text { industry. Its stakeholders are } \\
\text { video game teams, leagues, } \\
\text { casinos, betting sites, } \\
\text { tournaments, broadcasters, and } \\
\text { people that buy the data. }\end{array}$}} & $\begin{array}{l}\text { Societal Culture } \\
\text { The entrepreneur admitted that } \\
\text { many people see taking bets on } \\
\text { video games as "degenerative } \\
\text { behaviour," but reasoned that } \\
\text { people are allowed to do what } \\
\text { they want in life. }\end{array}$ & \multirow[t]{2}{*}{$\begin{array}{l}\text { End-User } \\
\text { R.ai can potentially contribute to } \\
\text { the life of the end-user, whether } \\
\text { that be the casino, bettor, or } \\
\text { video gamer, by aiding in their } \\
\text { ability to make money. }\end{array}$} \\
\hline & $\begin{array}{l}\text { Employees } \\
\text { R.ai's team is comprised of five } \\
\text { main employees. The entrepreneur } \\
\text { has been building technology } \\
\text { teams for around } 20 \text { years, and } \\
\text { keeps the same top employees } \\
\text { through each project. The } \\
\text { entrepreneur stated that he offers } \\
\text { competitive salaries and believes } \\
\text { people like to work for him. }\end{array}$ & & & $\begin{array}{l}\text { Scale of Outreach } \\
\text { R.ai plans to hire a few more } \\
\text { people to take on the opportunity } \\
\text { to make casinos their main target } \\
\text { market. }\end{array}$ & \\
\hline \multicolumn{3}{|c|}{$\begin{array}{l}\text { Social Impacts } \\
\text { The entrepreneur admitted that there is a negative social view or perception around } \\
\text { video games and especially betting on video games. The entrepreneur believes R.ai } \\
\text { could do a better job at communicating its values to the community, in order to mitigate } \\
\text { this perception. }\end{array}$} & \multicolumn{3}{|c|}{$\begin{array}{l}\text { Social Benefits } \\
\text { The entrepreneur believes that in addition to helping people make money, R.ai does try } \\
\text { to educate the public about the potential in the video game industry, whether that be } \\
\text { through playing as a professional or all the job opportunities in gaming. The } \\
\text { entrepreneur explained that there is a lot more to the industry outside of playing or } \\
\text { making games, including running tournaments, planning leagues, and establishing } \\
\text { partnerships. }\end{array}$} \\
\hline
\end{tabular}

Figure 8: Rival.ai's Social Layer 
5. The entrepreneur finds the fact that coal constitutes the majority of the world's electricity supply to be alarming, stating that he/she does not like coal at all. The entrepreneur believes governments need to do more with renewable energy plants, in order to make renewable energy an option for businesses.

6. The entrepreneur believes technology companies will be a driving force toward sustainability. Specifically, big technology companies need to be a leader in the space to develop renewable options in order for smaller companies, like R.ai, to make better choice. The entrepreneur believes that "one day, all of technology infrastructure will be green, it is just a matter of time." The entrepreneur states that in the meantime, it is R.ai's job to keep apprised of these developments in order to make better choices for the health of the planet.

\subsection{SkillShark}

SkillShark (SS) offers a software designed for sports evaluation. The software allows for better organization, efficiency, and flexibility than manual entry when scouting athletes. Organizations can use pre-built or customizable templates to enter attributes for evaluation. Evaluators then use the mobile app or website to score athletes. The software computes and normalizes the results to be more accurate. The software also has the option to provide feedback to athletes and parents. SS's Environmental Layer can be seen in Figure 9 and its Social Layer can be seen in Figure 10.

Environmental General. The entrepreneur stated that using the website or app to gather data rather than paper is the main environmental component that provides value to SS. Additionally, recycling is the main environmental consideration in the operational side of the business. The entrepreneur noted that it is the norm for people these days to be more environmentally conscious. Within the company, the entrepreneur does not even need to enforce 
environmental policies, as people are more environmentally aware to do the right thing. Asked if having environmental considerations in their business model could help them receive funding from VCs, the entrepreneur stated that, from experience, investors would care very little about the environmental effect.

Social General. When asked if having social considerations in their business model could help them receive funding from VCs, the entrepreneur stated that if it did it would only be from a feature aspect, as most VCs are only interested in revenue. 


\section{Environmental Layer}

\begin{tabular}{|c|c|c|c|c|c|}
\hline \multirow[t]{2}{*}{$\begin{array}{l}\text { Supplies and Outsourcing } \\
\text { SS outsources certain coding } \\
\text { responsibilities and product } \\
\text { design tasks if it is a skill that the } \\
\text { development team does not have. } \\
\text { Additionally, SS uses a cloud } \\
\text { service for data storage. }\end{array}$} & $\begin{array}{l}\text { Production } \\
\text { SS's development team spends a } \\
\text { number of hours each day } \\
\text { creating code to add features } \\
\text { and enhance the product for } \\
\text { customers. }\end{array}$ & \multirow{2}{*}{\multicolumn{2}{|c|}{$\begin{array}{l}\text { Functional Value } \\
\text { SS's software offers a } \\
\text { customizable athlete evaluation } \\
\text { that helps save time, removes } \\
\text { data entry, and produces more } \\
\text { accurate evaluations of athletes. }\end{array}$}} & $\begin{array}{l}\text { End-of-Life } \\
\text { The entrepreneur did not specify } \\
\text { what happens to the data once it } \\
\text { is no longer needed organization } \\
\text { or athlete. }\end{array}$ & \multirow{2}{*}{$\begin{array}{l}\text { Use Phase } \\
\text { SS provides sports organizations } \\
\text { a template editor to allow them } \\
\text { to customize the software to use } \\
\text { whatever metrics they want to } \\
\text { include in the evaluation. The } \\
\text { built template is then exposed to } \\
\text { evaluators who use that to fill } \\
\text { out the templates per athlete } \\
\text { through the website or through } \\
\text { the SS app on their phone. Once } \\
\text { the evaluators have finished } \\
\text { scouting the athletes, the } \\
\text { software manipulates the data } \\
\text { based on what the organization } \\
\text { is looking for. If the organization } \\
\text { chooses to release the report, } \\
\text { athletes can view their report by } \\
\text { creating an account on the } \\
\text { website. }\end{array}$} \\
\hline & $\begin{array}{l}\text { Materials } \\
\text { The main materials that are used } \\
\text { by SS are computers and office } \\
\text { buildings, additionally SS data } \\
\text { are stored via cloud. The } \\
\text { entrepreneur stated that no } \\
\text { environmental considerations } \\
\text { were given when choosing these } \\
\text { materials. }\end{array}$ & & & $\begin{array}{l}\text { Distribution } \\
\text { Most customers find out about } \\
\text { SS from digital media, whether } \\
\text { through search engines or social } \\
\text { media ads. Customers can then } \\
\text { go to the website and create an } \\
\text { account. }\end{array}$ & \\
\hline \multirow{2}{*}{\multicolumn{3}{|c|}{$\begin{array}{l}\text { Environmental Impacts } \\
\text { The entrepreneur does not believe there are any negative environmental impacts that are } \\
\text { a result of their business. }\end{array}$}} & \multicolumn{3}{|c|}{ Environmental Benefits } \\
\hline & & & \multicolumn{3}{|c|}{$\begin{array}{l}\text { The entrepreneur stated that SS's main contribution to environmental benefits is through } \\
\text { eliminating the need for paper usage. The entrepreneur stated that one small evaluation } \\
\text { would result in reams of paper that would be "consumed, looked at for a few hours, and } \\
\text { thrown in the garbage." With SS, it completely eliminates the need for paper. }\end{array}$} \\
\hline
\end{tabular}

Figure 9: SkillShark's Environmental Layer 


\section{Social Layer}

\begin{tabular}{|c|c|c|c|c|}
\hline \multirow{2}{*}{$\begin{array}{l}\text { Local Communities } \\
\text { When SS becomes a profitable } \\
\text { entity, the entrepreneur wants to } \\
\text { give back to local communities, } \\
\text { specifically Saskatchewan, where } \\
\text { they are based. Additionally, SS is } \\
\text { currently planning to partner with } \\
\text { some smaller professional sports } \\
\text { leagues, but did not specify } \\
\text { which. }\end{array}$} & $\begin{array}{l}\text { Governance } \\
\text { The entrepreneur's goal is to be } \\
\text { a privately owned for profit } \\
\text { company. }\end{array}$ & \multirow{2}{*}{$\begin{array}{l}\text { Social Value } \\
\text { The entrepreneur believes SS's } \\
\text { social value is through reducing } \\
\text { the strain put on coaches for } \\
\text { every sport, by making their job } \\
\text { easier and saving them between } \\
40-60 \text { hours per athletic } \\
\text { evaluation. Additionally, the } \\
\text { entrepreneur believes their social } \\
\text { value is also through providing } \\
\text { better feedback to young athletes } \\
\text { and parents. }\end{array}$} & $\begin{array}{l}\text { Societal Culture } \\
\text { The entrepreneur believes that SS } \\
\text { can positively influence society } \\
\text { through job creation, data } \\
\text { transparency, and feedback in } \\
\text { youth sports. }\end{array}$ & \multirow{2}{*}{$\begin{array}{l}\text { End-User } \\
\text { SS benefits two different end-users: } \\
\text { sports organizations and athletes. } \\
\text { SS benefits the sports organizations } \\
\text { by saving the organization time } \\
\text { from not having to do data entry, } \\
\text { removing stress, and providing } \\
\text { more accurate and adaptable data. } \\
\text { SS benefits athletes by being able to } \\
\text { rank the athletes more accurately, } \\
\text { thus will be put on the team they } \\
\text { deserve to be playing on and } \\
\text { therefore will have a better } \\
\text { experience. SS also benefits athletes } \\
\text { by providing better feedback to } \\
\text { them about their performance and } \\
\text { competition level. The entrepreneur } \\
\text { did not specify how SS handles data } \\
\text { privacy and security efforts } \\
\text { regarding the data on athletes. }\end{array}$} \\
\hline & $\begin{array}{l}\text { Employees } \\
\text { SS currently has twelve full-time } \\
\text { or part-time employees, } \\
\text { consisting of a CEO, software } \\
\text { developers, and their marketing } \\
\text { team. The entrepreneur foresees } \\
\text { SS growing to about } 30 \\
\text { employees in the next year } \\
(2020) \text {, and then } 50-100 \text { in the } \\
\text { year after that (2021). }\end{array}$ & & $\begin{array}{l}\text { Scale of Outreach } \\
\text { SS is used around the world and } \\
\text { currently has } 20 \text { sport templates in its } \\
\text { library and evaluation templates for } \\
\text { coaches, referees, umpires, and } \\
\text { officials. SS's current main users are } \\
\text { youth hockey and baseball } \\
\text { organizations, but the entrepreneur } \\
\text { expects that to shift towards soccer and } \\
\text { volleyball, as those are the two globally } \\
\text { dominant sports. The entrepreneur } \\
\text { believes that once SS gets into higher- } \\
\text { end data analytics, professional sports } \\
\text { teams will use SS rather than spending } \\
\text { millions of dollars on funding their own } \\
\text { IT departments. }\end{array}$ & \\
\hline \multicolumn{2}{|c|}{$\begin{array}{l}\text { Social Impacts } \\
\text { The entrepreneur does not see any negative social impacts of SS. }\end{array}$} & \multicolumn{3}{|c|}{$\begin{array}{l}\text { Social Benefits } \\
\text { SS benefits society by allowing better feedback to young athletes, who typically never } \\
\text { receive any feedback on what they do well or how they can develop, thus creating a } \\
\text { better experience for them. This can increase their confidence by knowing what it is } \\
\text { they are doing well and increasing their ability because they know what they need to } \\
\text { work on. Additionally, SS relieves stress from the lives of coaches and sports } \\
\text { organizations, increase communication between organization and athletes, and provide } \\
\text { everyone, including parents, athletes, organizations, evaluators, and coaches, a much } \\
\text { more positive experience. }\end{array}$} \\
\hline
\end{tabular}

Figure 10: SkillShark's Social Layer 


\subsection{DISCUSSION}

This section discusses the presence of current environmental and social considerations in the business models of the three start-ups, as well as what environmental and social considerations should have been included for a SBM according to Joyce and Paquin (2016). The entrepreneurs' views on potential future environmental and social considerations of the entrepreneurs as well as their general opinions about sustainability are also discussed. Finally, the entrepreneurs' viewpoints on VCs' opinions of sustainability activities in relation to the literature review is examined.

\subsection{Performance Phenomics}

This section discusses the current and potential environmental and social considerations of PP that arose from the discussion during the interview, as well as the entrepreneur's views on sustainability activities in general. It also discusses the entrepreneur's views on the effect incorporation environmental and social considerations have on receiving funding from VCs.

\section{Environmental Considerations}

The discussion with the entrepreneur from PP resulted in only one current environmental consideration in the start-up. The entrepreneur explained that, as a workforce split between two cities, PP tries to limit frequent travel by utilizing video conferencing technologies as much as possible for weekly meetings. This consideration can be applied to the Production building block in the environmental layer, as PP is utilizing video conferencing for meetings in order to produce its service, which emit far less emissions, as opposed to transporting people to various cities frequently.

The entrepreneur could not identify any other environmental considerations in the other building blocks in the TLBMC. Additional environmental considerations that could have been 
identified include energy usage, which falls under Supplies and Outsourcing, as well as office buildings, computers, and information technology, which are in the Materials building block. Distribution is a key building block that the entrepreneur also did not identify as having any environmental consideration. As PP relies on medical systems to administer the MRIs, and they only have a few "point people" in geographic areas, this has some major environmental implications. Their current distribution model has patients travelling to certain hospitals or medical centres that PP has a "point person" at in order to get a specific MRI that PP can then run through its algorithm. Even if a patient had already had a previous MRI, they would need to get a new one in order to get the correct set of scans that PP needs. This distribution model that relies on patients travelling potentially long-distances to get an MRI can be considered a negative Environmental Impact. This was not realized by the entrepreneur, nor was any mention of potentially changing PP's distribution model.

Additionally, when asked if there were any potential negative Environmental Impacts of the start-up, the entrepreneur did not believe there were any. This "no answer" may be considered an answer in that the entrepreneur simply may not understand the relationship between the startup and the environmental effects. Overall, PP only had one environmental consideration, limiting frequent travel, in its business model.

\section{Social Considerations}

While PP only had one environmental consideration, it did have some social considerations in its business model. This was witnessed in the interview as the majority of the discussion revolved around the social features and benefits of PP. The main social consideration in PP's business model is the importance it places on insuring data management and information privacy, which can be witnessed in the Social Benefits building block, as it aims to reduce the potential 
leak of private information. This reflects the findings by Grigore et al. (2012) that new responsibilities in digital technology lay in information privacy and data use, among other things. The entrepreneur also identified Societal Culture as an important building block to PP, as they work to positively impact society through advancing care for stroke and concussion patients. The entrepreneur also identified End-User as an important building block to PP, as the entrepreneur believes the report will help both the patient receive the best care possible and the physician give the best care possible.

The entrepreneur could not identify any social considerations regarding Local Communities, Governance, and Employees. While the entrepreneur did identify relationships PP had with Local Communities and its "point people," there was no discussion regarding how those relationships are managed and if they are also beneficial to those health centres or "point people." For the Governance building block, there was no discussion regarding internal organization structure and decision-making policies PP may have. Additionally, regarding Employees, the entrepreneur did not discuss any considerations regarding hiring policies, pay, employee demographics, and employee-oriented programs.

When asked if PP had any potential negative social impacts, the entrepreneur responded that there were no concerns on the social side. Again, similar to the inability to identify any negative environmental impact, this "no answer" may still be an answer in that the entrepreneur may truly not be aware of the negative social impacts or may not want to point out any potential weaknesses in PP. Overall, PP does have current social considerations in the areas of Societal Culture, End-User, and Social Benefits in its business model. 


\section{Potential Future Considerations/Views on Sustainability Activities}

There was one potential future social consideration for PP in the Local Communities building block, as the entrepreneur wants to eventually partner with sports, military, or stroke communities. Regarding views on sustainability, he entrepreneur does believe that ICT is a driver for sustainable development, specifically through allowing for more productive and remote work, thus limiting the negative environmental effects of plane travel. While this is definitely a benefit to the environment, it is also only one small aspect of the potential for sustainability as a result of ICT, such as reducing energy usage and diminishing material goods.

\section{Sustainability Activities and VCs}

When discussing the role environmental considerations may play in receiving funding from VCs, the entrepreneur acknowledged a growing focus on the environmental impacts of businesses from VCs.

"I think there is an extreme movement towards that ESG (environmental, social, and governance) focus of investor and think that everyone really does want to know what the global impact of what you're working on is, not just how it is going to make money."

Additionally, the entrepreneur also believes that having a social aspect in their business has helped them receive funding.

"Everybody that I have met with, who has given us funding, has been affected by... stroke or concussion or neuro-degeneration, so it is something that hits home with people and I think that it does play an impact in the decision of whether they want to fund the business or not."

"Impact investing will drive dollars away from companies that have a mindset of profit at all costs. This will be the rising tide for the social and responsible companies."

The entrepreneur's view regarding sustainability considerations, specifically social considerations, playing a role in receiving funding from VCs somewhat reflects the findings by de Lange (2017). While de Lange (2017) found that VCs typically avoid sustainable start-ups, 
particularly environmentally sustainability ones, investors do slightly favour start-ups that are profit-driven, but do address some sort of social issue, which is the type of start-up PP falls under. Additionally, in Canada in 2019, life science, which includes biotechnology, was the second most invested in industry after ICT (CVCA, 2020).

As PP is a software company that services stroke and concussion patients and the healthcare community, it benefits from being in the top two invested-in industries. The facts that PP falls into the two most heavily invested industries and is a profit-driven company that does address a social issue may explain why the entrepreneur believes that VCs are interested in the social aspect of start-ups. However, it is interesting to note that while the entrepreneur also believes that VCs are interested in the environmental impacts of a start-up, the start-up does not have any environmental consideration in the business model.

\subsection{Rival.ai}

This section highlights the various current and potential environmental and social considerations that were discussed in the interview and the follow-up responses with R.ai. The entrepreneur's views on technology and sustainability, as well as sustainability activities and VCs are discussed.

\section{Environmental Considerations}

R.ai had environmental considerations in some of the building blocks of the TLBMC, including Supplies and Outsourcing, Production, Materials, and Environmental Benefits. Its main environmental consideration, the use of cloud computing, is in the Supplies and Outsourcing building block. While all of the start-ups use cloud services for data storage or servers, only the entrepreneur from R.ai, identified cloud computing as having a potential environmental benefit. 
"I think cloud based computing is going to have the biggest impact on the environment. Because five years ago, we would have multiple servers [in the office] running big machines plugged into the wall sucking juice. Now, instead of every AI having its own server, we just rent a cloud server as a virtual machine from Amazon, so it's not a real computer, it's like a mega machine that has hundreds of clients, and we are just one client on that server. So the whole [movement] to improve the efficiency of online cloud computing results in a lot less electricity, a lot less computers needed to buy."

As discussed in the literature review, cloud computing does provide increased energy efficiency compared to using traditional on-site data centres (Accenture Microsoft Report, 2012). As most of R.ai's functional value is created and used digitally, using energy efficient cloud computing may be the most impactful environmental consideration. Additionally, as only R.ai seemed to have known this, it may be overreaching to suggest that increased energy efficiency was a factor in the decision to use cloud services for the other start-ups, but may have been one for R.ai. As R.ai mainly uses energy from cloud computing in the Materials and Production building blocks, this environmental consideration can also be applied there too. Additionally, the entrepreneur also noted that R.ai tries to run a "tight" office, in that they limit paper waste. This can also be considered an environmental consideration in the Production building block. However, the entrepreneur could not identify any other environmental considerations for the Materials building block, which could have included the computers or office building they use. Along with that, the entrepreneur noted that cloud gaming will likely rise in popularity and replace existing console-based gaming, which will also reduce negative environmental effects through increased energy efficiency and less material production.

Other environmental considerations that arose from the interview and response were reducing plane travel and giving staff local commuter passes, which can be characterized as Environmental Benefits, as they aim to reduce emissions. The entrepreneur explained that aside from these considerations, it is difficult for R.ai to do much more because their "hands are tied," 
meaning they are subject to the larger systems, such as cloud server companies and energy providers. Overall, the main environmental consideration in R.ai's business model is its use of cloud computing, which can fall under the Supplies and Outsourcing, Materials, and Production building blocks. There was no discussion around the Distribution, End-of-Life, and Use Phase environmental considerations.

\section{Social Considerations}

Through discussion during the interview and responses to the follow-up questions, a few social considerations in R.ai's business model were revealed. For one, the entrepreneur explained that R.ai can empower one of the End-Users, the video gamers, to be paid what they are worth, as the AI can determine the skill level of the player, the recognition can help players obtain sponsorship deals, get on pro teams, and get into larger tournaments which pay more. Additionally, R.ai also tries to educate youth gamers about the potential job opportunities in the video game industry, which falls under Scale of Outreach. R.ai does this through going to tradeshows, speaking at conferences, working with various school teams, and hosting tournaments. However, while this was identified as a social consideration, it could also be seen as R.ai trying to further their business plan and increase publicity. The entrepreneur also explained what social considerations R.ai has regarding Governance, specifically, ownership, internal organizational structure, and decisionmaking policies. R.ai also has a few social considerations for Employees building block, specifically that the employees are offered competitive salaries and public transportation passes.

However, social considerations were not identified for Local Communities, Societal Culture, and End-User. Social considerations for the Local Communities building block identified, may have include relationships R.ai has with casinos, video game teams, and leagues. One major social consideration that was not discussed was Societal Culture and End-User, specifically how 
R.ai impacts society and all of the End-Users. As there are many negative effects associated with gambling and video games, it may be hard to explain how R.ai can positively influence society. Additionally, as R.ai has potentially three End-Users, the casinos, bettors, and gamers, there should be social considerations made for all three regarding how R.ai can affect their quality of life. However, there was no discussion regarding the potential negative effects that could result from betting on video games, including financial loss or addiction. Finally, as R.ai's main value is from the AI that watches the video game streams, it is worth noting that there could be potential property or intellectual rights issues regarding the data that the AI obtains, which can be a negative Social Impact.

Overall, there were some social considerations in R.ai's business model, specifically in Governance, Employees, and Scale of Outreach. However, some major social considerations were not identified, including relationships within Local Communities, R.ai's impact on Societal Culture, and the potential negative effects of gambling for End-Users.

\section{Potential Future Considerations/Views on Sustainability Activities}

The entrepreneur did identify some potential future environmental considerations and explained how R.ai might incorporate them into its business model. This is illustrated in the entrepreneur's belief that, in time, there will be green technology infrastructure, specifically web hosting that uses $100 \%$ renewable resource, and it is R.ai's job to be aware of when this technology comes to market. It displays that the entrepreneur is aware of the environmental effects of the startup, but is currently not in the position to incorporate larger environmental considerations, such as using green technology. In terms of the future social considerations, the discussion did not reveal any potential future social considerations for R.ai. 
The entrepreneur also made some interesting points about sustainability and technology; explaining that the ways to do good for the environment with technology are less prevalent than to do well by people. Follow-up responses also indicate that the entrepreneur believes the government can do more to incentivize businesses. This shows that even though R.ai may have intentions to include sustainability activities, there still needs to be a financial motive for it to include sustainability in the business model.

\section{Sustainability Activities and VCs}

It was apparent that the entrepreneur does not believe sustainability activities would help start-ups receive funding from VCs. When asked if having environmental considerations in their business model could potentially play a role in receiving funding from VCs, the entrepreneur made it very clear that they would not.

"VCs don't care...I went through a process of raising for six months, so it was just non-stop VC meetings, none of them ever asked me about the environment. And if I would have told them what we are doing with the environment, they would have just glazed over."

Additionally, the entrepreneur does not believe having environmental considerations would even be a differentiating factor for VCs, although he did reason that it might be helpful if R.ai were an actual environmental company, but as a video game company selling data to casinos, no one expects that of them.

This echoes de Lange's (2017) findings that VCs generally do not care about a start-up's environmental sustainability, and thus are not more inclined to fund them. However, research did show that there has been an increase in capital directed toward sustainable innovations (Boons et al., 2003; Ethical Media Markets, 2018). These findings may relate to the point that the entrepreneur from R.ai made about not being an environmentally focused product. 
"If we [were] an environmental company producing like bio-fuels or recycled technology or some type of sustainability value proposition where that becomes the core basis, then I can see that [having environmental considerations] being part of the narrative. But like, we are a video game company, dealing with AI, selling to casinos, no one asks us about that."

This point reaffirms the findings of Mrkajic et al. (2019) that having environmental considerations may help receive funding if the start-up was based on environmental technologies or products and in an environmental sector. So while there are increased funding towards environmentally sustainable innovation, it may be that funding is only going towards start-ups in an environmental sector that have an innovation that is specific to solving an environmental issue. Increased funding may be going towards these environmental innovations, but innovations outside this space are not likely to benefit from having environmental considerations (de Lange, 2017; Mrkajic et al., 2019).

When asked about social considerations playing a role in receiving funding, the entrepreneur explained that all VCs care about is money.

“[R.ai has] met with maybe forty or fifty of [VCs] and they don't care about anything but their return on investment, all they care about is your projected revenue, how are you going to get there, and what is the likelihood that you can turn it into a 100 million dollar company. Like they don't ask us about our hiring policy, they don't ask us about social influence, they don't ask us about our sustainability or environmental footprints. They literally only care about how much money you can make them, that's all they're in it for."

The entrepreneur's perceptions largely reflect de Lange's (2017) findings that not only do VCs not favour start-ups that display features of sustainability; they avoid entrepreneurs that are anything other than a profit-only focus.

\subsection{SkillShark}

SS's current and potential environmental and social considerations are discussed in this section, along with the entrepreneur's views on sustainability activities and VCs. As the 
entrepreneur did not respond to the follow-up questions, this section is not as detailed as the sections for PP and R.ai.

\section{Environmental Considerations}

There were few environmental considerations revealed from the discussion with the entrepreneur from SS, both of which are in the Environmental Benefits building block. The only environmental consideration that the entrepreneur identified was in the operational side of the business, noting that they recycle in the office. Additionally, the entrepreneur did not identify any aspects of SS that could have a negative effect on the environment, but that in fact there are only positive effects.

"It is pretty much all positive, [SS is] eliminating the need for paper usage and... in one small [athletic] evaluation that might happen in a year, there would be inches thick of paper that gets consumed and looked at for a couple hours and then thrown in the garbage. With SS, we are removing the usage of that paper."

While this is definitely a step in the right direction in terms of eliminating unnecessary waste, this can also be viewed as sort of a surface level environmental consideration. While reducing paper usage and recycling is not something to discredit, in order to achieve a truly sustainable start-up/business, entrepreneurs need to do much more than limit paper usage. Though this can be identified as an environmental consideration, decreasing paper usage may also simply be a side effect of the nature of the start-up as a software company.

There were no environmental considerations in the business model for Supplies and Outsourcing, Production, Materials, Distribution, and Use Phase. The entrepreneur identified computers and office buildings as SS's main elements in the Materials building block, and what are also used in the Production, but stated no environmental considerations were included when picking the type of office building or computers. Additionally, no environmental considerations were identified in the Distribution or Use Phase, which include customers using their own 
computers, tablets, or phones to download and use the software. The entrepreneur also did not identify how much energy is needed to download or use the app, which can be a key environmental consideration for those building blocks.

Overall, the entrepreneur only identified limiting paper waste as an environmental consideration, which can be labeled as an Environmental Benefit. The entrepreneur did not identify any environmental considerations in the areas of Supplies and Outsourcing, Production, Materials, Distribution, Use Phase, or negative Environmental Impacts in SS’s business model.

\section{Social Considerations}

SS had a few social considerations in their business model, specifically in the Societal Culture and End-User building blocks. SS's contribution to Societal Culture is through job creation, data transparency, and better feedback in youth sports. There were also social considerations included in the End-User building block. There are technically two End-Users for SS; the sports organization that pays for and uses the software, as well as the athlete and parents who get feedback. SS did identify both of these groups as End-Users, and the entrepreneur believes SS is improving the quality of life for both groups.

The entrepreneur could not identify any social considerations identified for the

Governance, Employees, Scale of Outreach, and negative Social Impacts building blocks. When asked about Governance, the entrepreneur explained that they were a privately-owned for profit, but did not speak to any considerations regarding internal organization structure or decisionmaking policies. Additionally, for the Employees building blocks, the entrepreneur did not indicate if SS had any hiring policies, pay, employee demographics, and employee-oriented programs. For the Scale of Outreach building block, the entrepreneur did not identify any social considerations regarding their relationships with stakeholders, which could be different sports leagues or teams, 
as well as any planned or future outreach programs they might initiate. Finally, the entrepreneur also did not identify any negative Social Impacts. Similar to PP, the inability to identify any negative social impact may still be considered an answer in that the entrepreneur may truly not be aware of the negative social impacts or may not want to point out any potential weaknesses in SS.

Overall, SS did have social considerations for Local Communities, Societal Culture, and EndUser.

\section{Potential Future Considerations/Views on Sustainability Activities}

The entrepreneur did not reveal any potential future environmental considerations for SS. In terms of potential future social considerations in the Local Communities building block. The entrepreneur expressed that SS wants to give back to the community they are based in in Saskatchewan as well as partnering with local sports leagues SS does plan to give back to their local community, once they become a profitable entity. However, the entrepreneur did not specify exactly how they were going to give back to the community, so may still be an early thought.

\section{Sustainability Activities and VCs}

The entrepreneur from SS did not believe environmental or social considerations would play a role in receiving funding from VCs, as they typically only care about revenues.

"The perception of every investor that I have talked to would care very little as to the environmental effect of the business."

This reflects the viewpoint of the entrepreneur from R.ai, as well as de Lange's (2017) findings, that VCs focus on only profit-driven start-ups. 


\subsection{CONCLUSION}

Based on the interviews and subsequent responses to the follow-up questions, it can be concluded that current environmental and social considerations in the three start-ups are limited when compared to the types of considerations that should be included in a SBM according to Joyce and Paquin (2016). Additionally, while there is some thought by entrepreneurs for potential future

environmental and social considerations to be incorporated into the start-ups, there are a lot of conditional factors, such as profitability, availability of green technology, and government incentives, that would be needed before these considerations are to be incorporated.

However, as conceptualizing and designing a typical business model is undoubtedly a process, it can be presumed that this is also the case for designing and implementing a sustainable business model. As these results stem from a single interview and small set of follow-up questions, it may be short-sighted to consider these the end results for the potential of a sustainable business model for these three start-ups. Although, introducing a longer process-based approach to this study may have led to introducing biases or leading the entrepreneurs to certain answers, which would not have led to honest responses regarding views on sustainability considerations.

Both of the entrepreneurs who responded to the start-up questions believe that technology is a driver for sustainable development, but for different reasons. R.ai specified that technology will be a driver for sustainable development, specifically through green technology. While PP identified the ability to work remotely, thus limiting emissions from travel, as the biggest driver for sustainable development as a result of ICT.

Only one of the entrepreneurs believed that having environmental and social considerations could play a role in receiving funding from VCs. It was very evident the other two entrepreneurs did not believe it would be beneficial in terms of receiving funding. One possible explanation for 
these pessimistic findings may be due to the types of VCs that these start-ups are meeting with. As VC firms tend to invest in specific industries, it may be possible that the VCs these start-ups met with were primarily interested in technology and profit-driven start-ups, as opposed to socially responsible or green start-ups. However, as both de Lange (2017) and Mrkajic et al. (2019) findings support the viewpoints of the entrepreneurs from R.ai and SS, it is more likely that the majority of VCs simply are not interested in start-ups incorporating sustainability aspects into business models. Thus, if VCs do not view having sustainability considerations as beneficial to a sustainable start-up, entrepreneurs may see no reason to include them. Overall, this project shows that these three start-ups may not have many enticing reasons to implement a sustainable business model, especially as software-based start-ups.

\subsection{Study Limitations}

One of the major limitations of this study is the limited number of entrepreneurs interviewed. Interviewing more entrepreneurs may have helped truly understand entrepreneur's views on incorporating environmental and social considerations into business models. However, given the consistency of limited responses in the majority of the answers from all three start-ups, especially concerning the lack of environmental thought given, it could indicate that other software-related start-ups are not likely to have environmental considerations as well.

There were also a couple of weaknesses noted in the interviews. First, based on personal observations of some of the reactions of the entrepreneurs, some of the questions may have been rather complex. While the interviewees were provided with an explanation of the TLBMC as well as the questions that would be asked, there seemed to be a bit of confusion around the exact purpose of the TLBMC and the terminology used. 
Another issue that was noticed during the interviews was the possibility that the entrepreneurs may not have wanted to admit or point out any potential weaknesses of their startups. This may be witnessed by the complete omission of any negative social impacts of the startup by two of the entrepreneurs.

The final weaknesses is similar to the one that is mentioned above in that it was noticed that the interviewees seemed to prefer to only talk about the positives and benefits of their product or service. While this may seem like an obvious talking point, it almost seemed like they were trying to sell their product or service, or possibly something an entrepreneur does instinctively (Gilmore \& Carson, 1999).

\subsection{Future Work}

Future work to follow this study could include replicating the interviews, with altered interview questions, with start-ups in a different industry or field. It may be interesting to see if there are any differences in responses with companies in a manufacturing industry, as these companies have generally been held under more scrutiny in terms of the environmental and social impacts of their products. Additionally, interviews with companies that did implement a sustainable business model could be interesting as well, in order to see the differences in environmental and social considerations included. Along with that, it could be beneficial to examine how these companies got over the barrier of receiving funding from venture capitalists who reportedly "don't care” about sustainability.

Further research may also be needed to understand how sustainability can be applied to software and ICT companies. As software and ICT are growing industries, it may be worthwhile to research what companies are currently doing in terms of sustainability in these industries, as 
well as potential further progress. This may lead to increased recognition of environmental and social concerns within these industries.

An extension to this research would be to undergo studies related to the perceptions of sustainability and sustainable business models from venture capitalists. Additionally, research regarding venture capitalists who do invest in green or sustainable companies could also be beneficial to understand what they believe makes a start-up sustainable and worth investing in.

Due to the limitations discussed regarding start-ups, it may also be interesting to conduct a similar study on mature software companies, in order to see if their responses are similar to the start-ups. 


\title{
APPENDICES
}

\section{APPENDIX A: Interview Questions}

\author{
Environmental Questions:
}

Functional Value - Describes the focal outputs of the product. Point of defining the functional unit is to clarify what is being examined in this layer.

- What would you describe as the overall service performance of your product?

- From a consumer aspect, what does a customer receive when using your product?

Materials - Key resources used by the organization to render the functional value.

- What are the main bio-physical stocks needed to produce your product?

- Consider materials required for information technology, computers, vehicles, and office buildings.

- Were environmental considerations given when picking these materials?

Production - Captures the actions taken by the organization to create value. Focus is on activities that are core to the organization and which have high environmental impact.

- What are the main activities that create value for your business?

- What is the flow of value for your business?

Supplies and Outsourcing - All other material and production activities that are used to render the functional value, but not considered core to the organization. In this case, think about all other business activities outside the ones used to create your product.

- Are there any other activities in the business that are not considered key to create value but that require materials?

- Do you outsource any activities?

- Did you consider the environmental impacts of the places you outsource to?

Distribution - The physical means by which the organization ensures access to its functional value.

- How is your product distributed?

- Any environmental implications considered when selecting the distribution network?

Use Phase - The impact of the clients partaking in the functional value, or core product. This includes maintenance and repair of products when relevant; and should include some consideration of the client's material resource and energy requirements through use.

- What material requirements are necessary for your product to be used by the consumer?

- Do you have any control over these materials?

End-of-Life - When the client chooses to end the consumption of the functional value. Entails issues of material reuse such as remanufacturing, repurposing, recycling, disassemble, incineration, or disposal of a product.

- Does your business's product have any environmental impact once reached end-of-life? Environmental Impacts - Addresses the ecological costs of the organization's actions. 
- Are there any aspects of your overall business operation that you would consider to have a negative effect on the environment?

- Are there realistically feasible means to change this?

- If not, what are the barriers to this?

Environmental Benefits - Extends the concept of value creation beyond purely financial value. From a sustainability perspective, this component provides space for the organization to explicitly explore product, and business model innovations that may reduce negative and/or increase positive environmental value through its actions.

- Are there any aspects of your overall business operation that you would consider to have a positive effect on the environment?

- This can include activities that are done to both reduce/minimize environmental impacts and create positive ecological value.

\section{Overall}

- What are the main components in the environmental layer that are most relatable to the function of your business?

- Which components do you believe would be the most realistic to change in order to reduce environmental impacts or produce environmental benefits within your business?

- Additionally, which building block do not relate to your business?

- Could your business benefit from incorporating environmental benefits or reducing environmental impacts?

- Do you think having environmental considerations in your business model could play a role in receiving funding from venture capitalists?

\section{Social Questions:}

Social Value - Speaks to the aspect of an organization's mission, which focuses on creating benefit for its stakeholders and society more broadly.

- How does your business create benefit for its stakeholders and society as a whole?

Employee - Considering the role of employees as a core organizational stakeholder.

- How were current employee

- $\quad$ s selected?

- Do you have any employee-oriented programs that contribute to the businesses long-term viability and success?

- Examples include training, professional development, and any support programs.

- What is the expected size of the business?

Governance - Captures the organizational structure and decision-making policies of an organization. Governance defines which stakeholders an organization is likely to identify and engage with and how the organization is likely to do so.

- What is the goal of ownership for your business?

- Examples include cooperative, privately owned for-profit, publicly owned forprofit 
- What does the internal organizational structure look like?

- Organizational hierarchy? Unit specialization?

- How are decision-making policies made?

Communities - Focuses on social relationships built with suppliers and local communities. An organization's success can be greatly influenced through developing and maintaining mutually beneficial relationships.

- Does your company have any current or planned future role in specific communities?

- How are relationships with suppliers managed?

Societal Culture - Recognizes the potential impact of an organization on society as a whole. Based on the concept that business cannot succeed if society fails. Societal culture leverages the concept of sustainable value to acknowledge an organizations potential impact on society, and how through its actions, it can positively influence society.

- How can your company positively influence society?

Scale of Outreach - Describes the depth and breadth of the relationships an organization builds with its stakeholders through its actions over time. May include the idea of developing long term, integrative relationships and the outreach of impact geographically.

- Plans for future expansion?

End-Users - The person who 'consumes' the value proposition. Addresses how the value proposition addresses the needs of the end-user, contributing to his/her quality of life.

- How does your company contribute to the quality of life for the end-user?

- Is the product structured differently for different demographics of end-user?

Social Impacts - Addresses the social costs of an organization.

- Concern with any particular measures of social impact?

- Examples of measures include working hours, cultural heritage, health and safety, community engagement, fair compensation, and respect of intellectual property rights.

Social Benefits - The positive social value creating aspects of the organization's action.

- Is your company concerned with creating aspects of positive social value?

- In what way?

\section{General}

- What are the main components in the social layer that are most relatable to your company?

- Do you see any areas for social improvement in the future for your company?

- Do you think having social considerations in your business model could play a role in receiving funding from $\mathrm{VCs}$ ? 


\section{APPENDIX B: Follow-Up Questions}

1. Since the last time we talked, have you become aware or thought of any other potential environmental or social impacts of your company?

2. Corporate social responsibility has long been incorporated in large manufacturing companies, however less so in digital technology companies. What do you think it means to be a responsible corporation as a technology/data company?

3. Scholars are suggesting that organizations should transition from the customary 'doless harm' thinking to more proactive 'do-no-harm' or better yet 'do-good' in terms of the natural environment and society. As an entrepreneur, what are your thoughts on this and how it applies to your business? Do you think a 'do-no-harm' or 'do-good' approach applies to your business?

4. Software sustainability and sustainable engineering are emerging fields for researchers as well as the industry. Currently, the information and communications technology (ICT) sector contributes around $2 \%$ of the global $\mathrm{CO} 2$ emissions, but an Ericsson sustainability report showed that ICT also has potential to actually help reduce greenhouse gas emissions by up to $15 \%$. What are your thoughts on this and how it relates to your product/service?

5. The information and communications technology (ICT) sector constitutes $10 \%$ of the world's electricity generation, and is growing. Studies have suggested that at the current rate, coal will still constitute up to 50\% of the electricity supply for the next decade. Do you find this alarming?

6. There has been a rise in the discussion on how digital information and communication technologies can play a role in sustainable development. As an entrepreneur of a technology company, do you see digital information and communication technologies as a barrier to or driver for sustainable development? 


\section{REFERENCES}

Accenture Microsoft Report. (2010). Cloud computing and sustainability: The environmental benefits of moving to the cloud.

https://www.wspenvironmental.com/media/docs/newsroom/Cloud_computing_and_Sus tainability_-_Whitepaper___Nov_2010.pdf

Adidas. (2017). Adidas sustainability progress report: 2016. https://www.adidasgroup.com/media/filer_public/08/7b/087bf055-d8d1-43e3-8adc$\underline{7672 f 2760 \mathrm{~d} 9 \mathrm{~b} / 2016 \text { adidas_sustainability_progress_report.pdf }}$

Aghion, P., Hemous, D., \& Veugelers, R. (2009). No green growth without innovation. Bruegel Policy Brief, 07.

Babiak, K., Mills, B., Tainsky, S., \& Juravich, M. (2012). An investigation into professional athlete philanthropy: Why charity is part of the game. Journal of Sport Management, 26(2), 159-176.

Babiak, K., \& Wolfe, R. (2009). Determinants of corporate social responsibility in professional sport: Internal and external factors. Journal of Sport Management, 23(6), 717-742. https://doi.org/10.1123/jsm.23.6.717

Baldassarre, B., Calabretta, G., Bocken, N. M. P., \& Jaskiewicz, T. (2017). Bridging sustainable business model innovation and user-driven innovation: A process for sustainable value proposition design. Journal of Cleaner Production, 147, 175-186.

https://doi.org/10.1016/j.jclepro.2017.01.081

Basiago, A. D. (1995). Methods of defining 'sustainability'. Sustainable Development, 3(3), 109119. https://doi.org/10.1002/sd.3460030302

Bocken, N. M. P. (2015). Sustainable venture capital - catalyst for sustainable start-up success? Journal of Cleaner Production, 108, 647-658. https://doi.org/10.1016/j.jclepro.2015.05.079

Bocken, N. M. P., Short, S. W., Rana, P., \& Evans, S. (2014). A literature and practice review to develop sustainable business model archetypes. Journal of Cleaner Production, 65, 4256. https://doi.org/10.1016/j.jclepro.2013.11.039

Boons, F., \& Lüdeke-Freund, F. (2013). Business models for sustainable innovation: State-ofthe-art and steps towards a research agenda. Journal of Cleaner Production, 45, 9-19. https://doi.org/10.1016/j.jclepro.2012.07.007

Boons, F., Montalvo, C., Quist, J., \& Wagner, M. (2013). Sustainable innovation, business models and economic performance: An overview. Journal of Cleaner Production, 45, 18. https://doi.org/10.1016/j.jclepro.2012.08.013 
Boons, F., \& Wagner, M. (2009). Assessing the relationship between economic and ecological performance: Distinguishing system levels and the role of innovation. Ecological Economics, 68(7), 1908-1914. https://doi.org/10.1016/j.ecolecon.2009.02.012

Borseman, M., Tanev, S., Weiss, M., \& Rasmussen, E. S. (2016). Lost in the canvases: Managing uncertainty in lean global startups. Paper presented at The International Society for Professional Innovation Management (ISPIM), Boston, Massachusetts. https://www.academia.edu/24157241/Lost_in_the_canvases_Managing_uncertainty_in_1 ean_global_startups

Broman, G. I., \& Robèrt, K.-H. (2017). A framework for strategic sustainable development. Journal of Cleaner Production, 140, 17-31. https://doi.org/10.1016/j.jclepro.2015.10.121

Bürer, M. J., \& Wüstenhagen, R. (2008). Cleantech venture investors and energy policy risk: An exploratory analysis of regulatory risk management strategies. In R. Wüstenhagen (Ed.), Sustainable innovation and entrepreneurship (pp. 290-309). Cheltenham, UK: Edward Elgar Publishing.

Clark, T., \& Charter, M. (2007). Sustainable innovation: Key conclusions from sustainable innovation conferences 2003-2006 organised by the centre for sustainable design. Farnham, UK: University for the Creative Arts.

Clinton L., Whisnant R. (2019) Business model innovations for sustainability. In G.G. Lenssen \& N.C. Smith (Eds.) Managing sustainable business (pp. 463-503). Dordrecht, NL: Springer https://doi.org/10.1007/978-94-024-1144-7_22

CVCA. (2020). Venture Capital Canadian Market Overview, 2019. https://central.cvca.ca/wpcontent/uploads/2020/03/CVCA_EN_Canada_VC_2019_Final-Mar13.pdf

De Haan, G. (2006). The BLK '21'programme in Germany: A 'Gestaltungskompetenz'-based model for education for sustainable development. Environmental Education Research, 12(1), 19-32. https://doi.org/10.1080/13504620500526362

De Lange, D. E. (2017). Start-up sustainability: An insurmountable cost or a life-giving investment?. Journal of Cleaner Production, 156, 838-854. https://doi.org/10.1016/j.jclepro.2017.04.108

Dentoni, D., Blok, V., Lans, T., \& Wesselink, R. (2012). Developing human capital for agri-food firms' multi-stakeholder interactions. International Food and Agribusiness Management Review, 15, 61-68. https://doi.org/10.22004/ag.econ.129178

Diesendorf, M. (2000). Sustainability and sustainable development. In D. Dunphy, J. Benveniste, A. Griffiths, \& P. Sutton (Eds.) Sustainability: The corporate challenge of the 21st century (pp. 19-37). Sydney, AS: Allen \& Unwin 
Dolter, B., \& Rivers, N. (2018). The cost of decarbonizing the Canadian electricity system. Energy Policy, 113, 135-148. https://doi.org/10.1016/j.enpol.2017.10.040

Elkington, J., Emerson, J., \& Beloe, S. (2006). The value palette: A tool for full spectrum strategy. California Management Review, 48(2), 6-28. https://doi.org/10.2307/41166336

Ellis, G., \& Weekes, T. (2008). Making sustainability 'real': Using group-enquiry to promote education for sustainable development. Environmental Education Research, 14(4), 482500. https://doi.org/10.1080/13504620802308287

Emerson, J. (2003). The blended value proposition: Integrating social and financial returns. California Management Review, 45(4), 35-51. https://doi.org/10.2307/41166187

Ericsson. (2019). Sustainability and corporate responsibility report 2019. https://www.ericsson.com/49353d/assets/local/about-ericsson/sustainability-andcorporate-responsibility/documents/2020/2019-sustainability-and-corporateresponsibility-report.pdf

Ethical Markets. (2018). 2018 green transition scoreboard report. St. Augustine, FL.

European Union. (2012). Small companies, big ideas. https://ec.europa.eu/environment/ecoap/about-eco-innovation/policiesmatters/eu/20121029-small-companies-big-ideas_en

Figge, F., \& Hahn, T. (2004). Sustainable value added - measuring corporate contributions to sustainability beyond eco-efficiency. Ecological Economics, 48(2), 173-187. https://doi.org/10.1016/j.ecolecon.2003.08.005

França, C. L., Broman, G., Robèrt, K.-H., Basile, G., \& Trygg, L. (2017). An approach to business model innovation and design for strategic sustainable development. Journal of Cleaner Production, 140, 155-166. https://doi.org/10.1016/j.jclepro.2016.06.124

Freudenreich, B., Lüdeke-Freund, F., \& Schaltegger, S. (2019). A stakeholder theory perspective on business models: Value creation for sustainability. Journal of Business Ethics, 1, 1-16 https://doi.org/10.1007/s10551-019-04112-z

Garetti, M., \& Taisch, M. (2012). Sustainable manufacturing: Trends and research challenges. Production Planning \& Control, 23(2-3), 83-104. https://doi.org/10.1080/09537287.2011.591619

Garg, S. K., \& Buyya, R. (2012). Green cloud computing and environmental sustainability. In S. Murugesan, \& G.R. Gangadharan (Eds.), Harnessing green IT: Principles and practices (pp. 315-340). Hoboken, NJ: Wiley.

Gibson, R. B. (2006). Sustainability assessment: Basic components of a practical approach. Impact Assessment and Project Appraisal, 24(3), 170-182. https://doi.org/10.3152/147154606781765147 
Gilmore, A., \& Carson, D. (1999). Entrepreneurial marketing by networking. New England Journal of Entrepreneurship, 2(2), 31. https://doi.org/10.1108/NEJE-02-02-1999-B004

Grigore, G., Molesworth, M., \& Watkins, R. (2017). New corporate responsibilities in the digital economy. In A. Theofilou, G. Grigore, A. Stancu (Eds.) Corporate social responsibility in the post-financial crisis era (pp. 41-62). London, UK: Palgrave Macmillan.

Grunwald, A. (2004). Strategic knowledge for sustainable development: The need for reflexivity and learning at the interface between science and society. International Journal of Foresight and Innovation Policy, 1(1-2), 150-167. https://doi.org/10.1504/IJFIP.2004.004619

Hall, J. K., Daneke, G. A., \& Lenox, M. J. (2010). Sustainable development and entrepreneurship: Past contributions and future directions. Journal of Business Venturing, 25(5), 439-448. https://doi.org/10.1016/j.jbusvent.2010.01.002

Herstatt C., Verworn B. (2004) The 'Fuzzy Front End' of innovation. In T. Durand (Ed.) Bringing technology and innovation into the boardroom (pp. 347-372). London, UK: Palgrave Macmillan

Hockerts, K., \& Wüstenhagen, R. (2010). Greening Goliaths versus emerging Davids: Theorizing about the role of incumbents and new entrants in sustainable entrepreneurship. Journal of Business Venturing, 25(5), 481-492. https://doi.org/10.1016/j.jbusvent.2009.07.005

Huijuan, C., Fujii, H., \& Managi, S. (2013). Environmental impact of the 2008 Beijing Olympic Games. Economics Discussion Papers, No. 2013-30. http://hdl.handle.net/10419/74472

IEA. (2019). Tracking power. http://www.iea.org/reports/tracking-power-2019/coal-fired-power

IESO. (2019). A progress report on contracted electricity supply. http://www.ieso.ca/en/Learn/Ontario-Supply-Mix/Ontario-Energy-Capacity

Inoue, Y., \& Kent, A. (2012). Sport teams as promoters of pro-environmental behavior: An empirical study. Journal of Sport Management, 26(5), 417-432. https://doi.org/10.1123/jsm.26.5.417

Joyce, A., \& Paquin, R. L. (2016). The triple layered business model canvas: A tool to design more sustainable business models. Journal of Cleaner Production, 135, 1474-1486. https://doi.org/10.1016/j.jclepro.2016.06.067

Kellison, T. B., \& Hong, S. (2015). The adoption and diffusion of pro-environmental stadium design. European Sport Management Quarterly, 15(2), 249-269. https://doi.org/10.1080/16184742.2014.995690 
Keuschnigg, C. (2004). Venture capital backed growth. Journal of Economic Growth, 9(2), 239261. https://doi.org/10.1023/B:JOEG.0000031428.35711.fc

Kiron, D., Kruschwitz, N., Haanaes, K., Reeves, M., \& Goh, E. (2013). The innovation bottom line. MIT Sloan Management Review, 54(3), 1-20.

Kocak, S. A. (2013). Green software development and design for environmental sustainability. Paper presented at the 11th International Doctoral Symposium an Empirical Software Engineering (IDOESE 2013), Baltimore, Maryland. https://www.umbc.edu/eseiw2013/idoese/pdf/eseiw2013_IDoESE_183.pdf

Kozlowski, A., Searcy, C., \& Bardecki, M. (2018). The reDesign canvas: Fashion design as a tool for sustainability. Journal of Cleaner Production, 183, 194-207. https://doi.org/10.1016/j.jclepro.2018.02.014

Kurucz, E. C., Colbert, B. A., Luedeke-Freund, F., Upward, A., \& Willard, B. (2017). Relational leadership for strategic sustainability: Practices and capabilities to advance the design and assessment of sustainable business models. Journal of Cleaner Production, 140, 189-204. https://doi.org/10.1016/j.jclepro.2016.03.087

Laasch, O. (2018). Beyond the purely commercial business model: Organizational value logics and the heterogeneity of sustainability business models. Long Range Planning, 51(1), 158-183. https://doi.org/10.1016/j.lrp.2017.09.002

Lans, T., Blok, V., \& Wesselink, R. (2014). Learning apart and together: Towards an integrated competence framework for sustainable entrepreneurship in higher education. Journal of Cleaner Production, 62, 37-47. https://doi.org/10.1016/j.jclepro.2013.03.036

Lindgreen, A., Vallaster, C., Maon, F., Yousafzai, S., \& Florencio, B. P. (2018). Sustainable entrepreneurship: Discovering, creating and seizing opportunities for blended value generation. London, UK: Routledge.

Lüdeke-Freund, F. (2010). Towards a Conceptual Framework of 'Business Models for Sustainability'. Paper presented at the $14^{\text {th }}$ European Roundtable on Sustainable Consumption and Production (ERSCP) \& $6^{\text {th }}$ Environmental Management for Sustainable Universities (EMSU) Conference, Delft, NL.

Mallen, C., Stevens, J., \& Adams, L. J. (2011). A content analysis of environmental sustainability research in a sport-related journal sample. Journal of Sport Management, 25(3), 240-256. https://doi.org/10.1123/jsm.25.3.240

Marcus, A., Malen, J., \& Ellis, S. (2013). The promise and pitfalls of venture capital as an asset class for clean energy investment: Research questions for organization and natural environment scholars. Organization \& Environment, 26(1), 31-60. https://doi.org/10.1177/1086026612474956 
Masanet, E., Shehabi, A., Lei, N., Smith, S., \& Koomey, J. (2020). Recalibrating global data center energy-use estimates. Science, 367(6481), 984-986. https://doi.org/10.1126/science.aba3758

McCullough, B. P., \& Cunningham, G. B. (2010). A conceptual model to understand the impetus to engage in and the expected organizational outcomes of green initiatives. Quest, 62(4), 348-363. https://doi.org/10.1080/00336297.2010.10483654

McCullough, B. P., Pfahl, M., \& Nguyen, S. (2016). The green waves of environmental sustainability in sport. Sport in Society, 19(7), 1040-1065. https://doi:10.1080/17430437.2015.1096251

McMullen, J. S., \& Warnick, B. J. (2016). Should we require every new venture to be a hybrid organization?. Journal of Management Studies, 53(4), 630-662. https://doi.org/10.1111/joms.12150

Mogensen, F., \& Schnack, K. (2010). The action competence approach and the 'new' discourses of education for sustainable development, competence and quality criteria.

Environmental Education Research, 16(1), 59-74. https://doi.org/10.1080/13504620903504032

Montalvo, C.C., Diaz-Lopez, F.J., \& Brandes, F. (2011). Potential for eco-innovation in nine sectors of the European Economy. Europe INNOVA. https://resolver.tudelft.nl/uuid:c3346da9-cd67-4168-bb0d-2d0a84a30d24

Mrkajic, B., Murtinu, S., \& Scalera, V. G. (2019). Is green the new gold? Venture capital and green entrepreneurship. Small Business Economics, 52(4), 929-950. https://doi.org/10.1017/s11187-017-9943-X

Naumann, S., Dick, M., Kern, E., \& Johann, T. (2011). The greensoft model: A reference model for green and sustainable software and its engineering. Sustainable Computing: Informatics and Systems, 1(4), 294-304. https://doi.org/10.1016/j.suscom.2011.06.004

Neumayer, E. (2003). Weak versus strong sustainability: Exploring the limits of two opposing paradigms. London, UK: Edward Elgar.

NIKE. (2019). FY18 NIKE, Inc. Impact Report.

Osterwalder, A., \& Pigneur, Y. (2010). Business model generation: A handbook for visionaries, game changers, and challengers. Hoboken, NJ: Wiley.

Ottman, J. (2017). The new rules of green marketing: Strategies, tools, and inspiration for sustainable branding. London, UK: Routledge.

Oyedeji, S., Seffah, A., \& Penzenstadler, B. (2018). A catalogue supporting software sustainability design. Sustainability, 10(7), 2296. http://doi.org/10.3390/su10072296 
Pacheco, D. F., Dean, T. J., \& Payne, D. S. (2010). Escaping the green prison: Entrepreneurship and the creation of opportunities for sustainable development. Journal of Business Venturing, 25(5), 464-480. https://doi.org/10.1016/j.jbusvent.2009.07.006

Parrish, B. D. (2010). Sustainability-driven entrepreneurship: Principles of organization design. Journal of Business Venturing, 25(5), 510-523. https://doi.org/10.1016/j.jbusvent.2009.05.005

Patton, M. Q. (2002). Qualitative research and evaluation methods. Newbury Park: Sage.

Pearce, D., Markandya, A., \& Barbier, E. B. (1989). Blueprint for a green economy. London, UK: Earthscan.

Pfahl, M. E. (2010). Strategic issues associated with the development of internal sustainability teams in sport and recreation organizations: A framework for action and sustainable environmental performance. International Journal of Sport Management, Recreation and Tourism, 6, 37-61. https://doi.org/10.5199/ijsmart-1791-874X-6c

Philips. (2018). Why sustainability matters for healthcare today - and patients in the future. https://www.philips.com/a-w/about/news/archive/blogs/innovation-matters/20180605why-sustainability-matters-for-healthcare-today.html

Porter, M. E., \& Kramer, M. R. (2011). Creating shared value. In G.G. Lenssen \& N.C. Smith (Eds.), Managing sustainable business (pp. 323-346). Dordrecht, NL: Springer

Randjelovic, J., O’Rourke, A. R., \& Orsato, R. J. (2003). The emergence of green venture capital. Business Strategy and the Environment, 12(4), 240-253. https://doi.org/10.1002/bse.361

Ratten, V. (2016). Sport innovation management: towards a research agenda. Innovation: Management, Policy \& Practice, 18(3), 238-250. https://doi.org/10.1080/14479338.2016.1244471

Rivoire, S., Shah, M. A., Ranganathan, P., \& Kozyrakis, C. (2007). JouleSort: A balanced energy-efficiency benchmark. Paper presented at Proceedings of the 2007 ACM SIGMOD International Conference on Management of Data. New York, NY.

Sartore-Baldwin, M. L., \& McCullough, B. (2018). Equity-based sustainability and ecocentric management: Creating more ecologically just sport organization practices. Sport Management Review, 21(4), 391-402. https://doi.org/10.1016/j.smr.2017.08.009

Sartore-Baldwin, M. L., McCullough, B., \& Quatman-Yates, C. (2017). Shared responsibility and issues of injustice and harm within sport. Quest, 69(3), 366-383. https://doi.org/10.1080/00336297.2016.1238769

SaskPower. (2019). Emissions. https://www.saskpower.com/Our-Power-Future/Powering2030/Emissions 
Schaltegger, S., Hansen, E. G., \& Lüdeke-Freund, F. (2016). Business models for sustainability: Origins, present research, and future avenues. Organization \& Environment, 29(1), 3-10. https://doi.org/10.1177/1086026615599806

Schaltegger, S., \& Wagner, M. (2011). Sustainable entrepreneurship and sustainability innovation: Categories and interactions. Business Strategy and the Environment, 20, 222237. https://doi.org/10.1002/bse.682

Schnack, K. (1996). Internationalisation, democracy and environmental education. In S. Breiting \& K. Nielsen (Eds.), Environmental education and health education (pp. 7-20). Copenhagen, DK: Danmarks Lærerhøjskole.

Shepherd, D. A., \& Patzelt, H. (2011). The new field of sustainable entrepreneurship: Studying entrepreneurial action linking "what is to be sustained" with "what is to be developed". Entrepreneurship Theory and Practice, 35(1), 137-163. https://doi.org/10.1111/j.1540$\underline{6520.2010 .00426 . x}$

Shevchenko, A., Lévesque, M., \& Pagell, M. (2016). Why firms delay reaching true sustainability. Journal of Management Studies, 53(5), 911-935. https://doi.org/10.1111/joms.12199

Sikdar, S. K. (2003). Sustainable development and sustainability metrics. AIChE Journal, 49(8), 1928-1932. https://doi.org/10.1002/aic.690490802

Stubbs, W. (2017). Sustainable entrepreneurship and B Corps. Business Strategy and the Environment, 26(3), 331-344. https://doi.org/10.1002/bse.1920

Stubbs, W., \& Cocklin, C. (2008). Conceptualizing a "sustainability business model". Organization \& Environment, 21(2), 103-127. https://doi.org/10.1177/1086026608318042

Thibault, L. (2009). Globalization of sport: An inconvenient truth. Journal of Sport Management, 23(1), 1-20. https://doi.org/10.1123/jsm.23.1.1

Trail, G. T., \& McCullough, B. P. (2018). Differential effects of internal and external constraints on sustainability intentions: A hierarchical regression analysis of running event participants by market segment. Journal of Management for Global Sustainability, 6(2), $1-36$.

Trail, G. T., \& McCullough, B. P. (2019). Marketing sustainability through sport: Testing the sport sustainability campaign evaluation model. European Sport Management Quarterly, 20(2), 1-21. https://doi.org/10.1080/16184742.2019.1580301 
Trendafilova, S., Babiak, K., \& Heinze, K. (2013). Corporate social responsibility and environmental sustainability: Why professional sport is greening the playing field. Sport Management Review, 16(3), 298-313. https://doi.org/10.1016/j.smr.2012.12.006

United Nations Environment Programme. (2009). Independent Environmental Assessment: Beijing 2008 Olympic Games. https://www.uncclearn.org/sites/default/files/inventory/unep36.pdf

United Nations Framework Convention on Climate Change. (2017). Sports representatives and the UN pitch for climate action. https://cop23.unfccc.int/news/sportsrepresentatives-and-the-un-pitch-for-climate-action

Upward, A. (2013). Towards an ontology and canvas for strongly sustainable business models: A systemic design science exploration (Unpublished doctoral dissertation). York University, Toronto, ON.

Upward, A., \& Jones, P. (2016). An ontology for strongly sustainable business models: Defining an enterprise framework compatible with natural and social science. Organization \& Environment, 29(1), 97-123. https://doi.org/10.1177/1086026615592933

Van der Velden, M. (2018). Digitalisation and the UN Sustainable development Goals: What role for design. Interaction Design and Architecture(s), (37), 160-174.

Vogel, D. (1992). The globalization of business ethics: Why America remains distinctive. California Management Review, 35(1), 30-49. https://doi.org/10.2307/41166711

WCED, (1987). Report of the World Commission on Environment and Development: Our common future. Oxford, UK: Oxford University Press.

Wiek, A., Withycombe, L., \& Redman, C. L. (2011). Key competencies in sustainability: A reference framework for academic program development. Sustainability Science, 6(2), 203-218. https://doi.org/10.1007/s11625-011-0132-6 
